Volume 9 | Issue 1

$11-2021$

\title{
The Jury Trial Reinvented
}

Christopher Robertson

Boston University School of Law, ctr00@bu.edu

Michael Elias Shammas

Tulane Law School, mshammas@tulane.edu

Follow this and additional works at: https://scholarship.law.tamu.edu/lawreview

Part of the Constitutional Law Commons, Courts Commons, and the Technology and Innovation Commons

\section{Recommended Citation}

Christopher Robertson \& Michael E. Shammas, The Jury Trial Reinvented, 9 Tex. A\&M L. Rev. 109 (2021). Available at: https://doi.org/10.37419/LR.V9.I1.3

This Article is brought to you for free and open access by Texas A\&M Law Scholarship. It has been accepted for inclusion in Texas A\&M Law Review by an authorized editor of Texas A\&M Law Scholarship. For more information, please contact aretteen@law.tamu.edu. 


\title{
THE JURY TRIAL REINVENTED
}

\author{
by: Christopher Robertson \& Michael Shammas*
}

\begin{abstract}
The Framers of the Sixth and Seventh Amendments to the United States Constitution recognized that jury trials were essential for maintaining democratic legitimacy and avoiding epistemic crises. As an institution, the jury trial is purpose-built to engage citizens in the process of deliberative, participatory democracy with ground rules. The jury trial provides a carefully constructed setting aimed at sorting truth from falsehood.

Despite its value, the jury trial has been under assault for decades. Concededly, jury trials can sometimes be inefficient, unreliable, unpredictable, and impractical. The COVID-19 pandemic rendered most physical jury trials unworkable but spurred some courts to begin using technology to transcend time-and-place limitations. These reforms inspire more profound changes.

Rather than abolishing or cabining the jury trial, it should be reinvented with the benefit of modern science and technology. Features to be reconsidered include having local juries even for national civil cases, using unrepresentative groups of only six to twelve jurors, allowing attorneys to arbitrarily exclude jurors during voir dire, having synchronous and chronological presentations of cases over days or weeks, asking jurors to ignore inadmissible evidence and arguments that arise during live trials, and relying on secretive deliberations infected by implicit bias.

Several of these extant practices work to disenfranchise or disempower Americans along racial, gender, and economic lines, thereby undermining one of the jury's core functions. Other features cause jurors to err in resolving cases accurately, which can sometimes mean the difference between life and death. A reinvented, modernized jury institution can better serve its purposes by increasing citizen engagement, better fostering civic education and democratic deliberation, improving accuracy in sorting truth from falsehood, and enhancing efficiency in terms of both time and cost.
\end{abstract}

\section{TABLE of Contents}

I. Introduction ............................... 110

II. Online Judicial Proceedings in 2020 \& $2021 \ldots \ldots . .116$

A. COVID-19's Effect on Civil Trials.............. 117

B. Criminal Trials \& the Speedy-Trial Guarantee ...... 122

DOI: https://doi.org/10.37419/LR.V9.I1.3

* Christopher Robertson: N. Neal Pike Scholar and Professor of Law, Boston University, ctr00@bu.edu. The author thanks Andrea Sharp and Katelyn Maxwell for invaluable research assistance; Jamie Robertson and Todd Proebsting for suggestions; and Bernard Chao and David Yokum, who have collaborated on related work. Robertson appreciates feedback from participants at the New York University Civil Jury Project's Academic Workshop and a faculty workshop at University of Arizona.

Michael Elias Shammas: Forrester Fellow \& Instructor of Legal Research \& Writing, Tulane Law School, mshammas@tulane.edu. Shammas's contributions to this article are partly informed by research completed in 2020 during a research fellowship at the New York University School of Law's Civil Jury Project as well as by considerations discussed during a 2019 conference organized by Ralph Nader and Rick Newman at the American Museum of Tort Law. 
III. Bringing Jury Trials into the 21st Century ...... 126

A. Larger Juries, Without Peremptory Challenges ...... 126

B. Asynchronous Video Presentation ................ 135

C. Shorter, Edited Trials ........................ 140

D. Breaking Time \& Place Limitations ............... 142

E. A National Jury Pool for National Civil Cases ...... 146

F. Vote-Aggregation Without Deliberation ............ 148

IV. Constitutionality \& Legal Reforms ............. 153

A. The Sixth and Seventh Amendments ............. 154

B. Public Justice ............................... 157

C. The Confrontation Clause...................... 158

D. The Implications for Procedural Rules ............ 160

V. Conclusion ................................... 163

\section{INTRODUCTION}

The COVID-19 pandemic has shaken American institutions, including key hallmarks of the judiciary like the jury trial. This institutional stress has occurred at a time when Americans are suffering from epistemic and democratic crises. The epistemic crisis reflects a modern difficulty in sorting fact from falsehood. ${ }^{1}$ A proliferation of conspiracy theories-involving everything from vaccine efficacy to "QAnon" to the 2020 presidential election-reflects the anxiety-provoking uncertainty that many Americans feel. At the same time, the democratic crisis reflects a country riven by a toxic yet understandable populism, marked by distrust of elites and "their" institutions. ${ }^{2}$ Targets of suspicion include Congress, administrative agencies (a.k.a. "the swamp," or "the deep state"), and state and federal courts, which were painted as corrupt or even malevolent during the 2020 presidential election. ${ }^{3}$

A reinvented American jury presents a partial solution to these epistemic and democratic crises, and the jolt of the coronavirus has loosened resistance to change. The necessity of reforming jury trials, and the opportunity to do so, has rarely been clearer.

1. See Yochai Benkler, Robert Faris \& Hal Roberts, Network Propaganda: Manipulation, Disinformation, and Radicalization in American Politics 4 (2018).

2. See Michael J. Klarman, Foreword: The Degradation of American Democracy-and the Court, 134 HARv. L. REv. 1, 16 (2020) ("[A]uthoritarian populists often attack the ruling elite as corrupt and promise to restore power to the people.").

3. See, e.g., Christopher D. Kromphardt \& Michael F. Salamone, "Unpresidented!" or: What Happens When the President Attacks the Federal Judiciary on Twitter, 18 J. Info. Tech. \& Pol. 84, 84, 89 (2021); Adam Liptak, Chief Justice Defends Judicial Independence After Trump Attacks 'Obama Judge', N.Y. TIMEs (Nov. 21, 2018), https://www.nytimes.com/2018/11/21/us/politics/trump-chief-justice-robertsrebuke.html [https://perma.cc/Y9DJ-N2EJ]; Darren Samuelsohn \& Josh Gerstein, Federal Judge Rebukes Trump over Roger Stone Jury Comments, Politico (Feb. 25, 2020, 3:18 PM), https://www.politico.com/news/2020/02/25/judge-rebukes-trumproger-stone-jury-117442 [https://perma.cc/KX6C-6MLP]. 
Consider the structure of government absent a well-functioning jury institution. In distributing power horizontally (across the federal government's three branches) and vertically (via powers reserved to the states), the Framers built many buttresses against populist rule. ${ }^{4}$ The Electoral College, for example, was largely designed "to ensure that elites directly picked the President." 5 And even the less aristocratic, more democratic Framers-for example, those behind the Seventh Amendment - failed to sufficiently anticipate the rise of political parties, which would eventually span all branches of government, consolidating power and undermining the common good. ${ }^{6}$ Because the existence of factions gives politicians strong incentives to fall in line, Congress can rarely be counted on to use powers like impeachment to check the President. ${ }^{7}$ Extreme partisanship has even given us reason to question the willingness of congressional partisans to reliably count Electoral College votes. ${ }^{8}$

Nonetheless, the Constitution's Framers-or at least those who rallied for a Bill of Rights - enshrined the right to trial by jury within the Sixth and Seventh Amendments. ${ }^{9}$ The amendments protected both a civic process for deliberative democracy unmediated by elites, and a means for reliably sorting truth from falsehood. ${ }^{10}$ As William Blackstone noted in 1783, the jury "preserves in the hands of the people that share which they ought to have in the administration of public justice, and prevents the encroachments of the more powerful and wealthy citizens." 11 With a robust jury, Americans need not rely on a corrupted political system to represent their interests; a (largely) ran-

4. Klarman, supra note 2, at 135 ("The Constitution's Framers wrestled with a perennial problem of representative government: how to prevent democratic majorities from redistributing property in their favor."); Daryl J. Levinson \& Richard H. Pildes, Separation of Parties, Not Powers, 119 Harv. L. Rev. 2311, 2313 (2006) ("[T] government that would effectively organize, check, balance, and diffuse power.").

5. Klarman, supra note 2, at 67.

6. See Levinson \& Pildes, supra note 4, at 2320.

7. David Crary, Impeachment a Rarely Used Path for Upending a President, AP News (Sept. 24, 2019), https://apnews.com/article/richard-nixon-donald-trump-ap-topnews-bills-politics-cd45ec8474fb4df080f5d98c1ecfba79 [https://perma.cc/S96S-X8R1].

8. See Jake Tapper, At Least 140 House Republicans to Vote Against Counting Electoral Votes, Two GOP Lawmakers Say, CNN (Dec. 31, 2020, 5:51 PM), https:// www.cnn.com/2020/12/31/politics/electoral-college-house-republicans/index.html [https://perma.cc/9BTK-28FL].

9. See Andrew Guthrie Ferguson, The Jury as Constitutional Identity, 47 U.C. Davis L. Rev. 1105, 1116 (2014) ("Jury trials, of course, predated the United States Constitution, but their almost universal acceptance in the colonies and then the newly formed states made them a central point of agreement in establishing the constitutional principles of government. Juries served as a reminder that citizens were the ultimate decision-makers in a democratic society." (internal citations omitted)).

10. See generally Suja A. Thomas, The Missing American Jury: Restoring the Fundamental Constitutional Role of the Criminal, Civil, and Grand JURIES (2016).

11. 3 William Blackstone, Commentaries *379-80. 
dom sample of everyday people does so directly and temporarily, averting problems of corruption and incumbency. ${ }^{12}$ And in the rarefied setting of a jury trial (unlike, say, social-media), citizens are empowered to deliberate at their best. Thanks to the Rules of Evidence, they are shielded (albeit imperfectly) from "irrelevant, unreliable, and prejudicial information." "It It is not difficult to see why the procedure by which juries make decisions may increase not only their legitimacy and authoritativeness but also that of the entire government, just as the Framers intended. ${ }^{14}$

Despite-or perhaps because of - its potential to foster democratic deliberation and increase epistemic legitimacy, the jury trial has been under assault for decades. ${ }^{15}$ Juries now resolve fewer than one in twenty cases. ${ }^{16}$ As some call for the jury's abolition and others work to stymie its impact, the Sixth and especially the Seventh Amendments face concerted, well-funded opposition. ${ }^{17}$ On the criminal side, plea

12. See Michael Elias Shammas, Commentary, Analysis: Do You Get a Jury Trial in Federal Condemnation Cases?, Civ. Jury ProJect NYU Sch. L., https:// civiljuryproject.law.nyu.edu/analysis-do-you-get-a-jury-trial-in-federal-condemnationcases/ [https://perma.cc/Z6W9-ELYA] ("[U]nlike experts (repeat players), jurors need not worry about their reputation, which in turn allows for greater honesty and for more disagreement among jurors. . . [D]isagreement heightens the likelihood that a group will come to an accurate conclusion ...."); Michael H. O'Donnell, Judge Extols Wisdom of Juries, IDAHO ST. J. (Aug. 16, 2014), https://www.idahostatejournal.com/ news/local/judge-extols-wisdom-of-juries/article_8dad172c-25.21-11e4-8891-

001a4bcf887a.html [https://perma.cc/T3AY-PAX7]; compare LAWRENCE LESSIG, They Don't Represent Us: Reclaiming Our Democracy xiii (2019) (describing institutional corruption in politics), with Christopher T. Robertson, Blinding as a Solution to Institutional Corruption 18 (Harvard Univ. Edmond J. Safra Ctr. for Ethics, Working Paper No. 21, 2013), http://ssrn.com/abstract=2321353 ("The jury 'represents' the public from which it is drawn in a statistical sense, rather than via the political process of electoral representation.").

13. Robertson, supra note 12, at 19; see also FED. R. Evid. 401, 403.

14. See generally David M. Estlund, Democratic Authority: A Philosophical Framework vii, viii (2008); Tom R. Tyler, Why People Obey the Law v, vi (2006).

15. See William G. Young, Vanishing Trials, Vanishing Juries, Vanishing Constitution, 40 Suffolk U. L. Rev. 67, 70-73, 76 (2006) ("[T]he American jury system is dying out-more rapidly on the civil than on the criminal side ... and more rapidly in the federal than in the state courts-but dying nonetheless." (quoting United States v. Reid, 214 F. Supp. 2d 84, 98 n.11 (D. Mass. 2002))); Martin H. Redish, Seventh Amendment Right to Jury Trial: A Study in the Irrationality of Rational Decision Making, 70 Nw. U. L. REV. 486, 508 (1975) ("[M]any would probably find the burdens of the civil jury so overwhelming that they would deny the constitutional right altogether, and give Congress total discretion as to when (if at all) the civil jury should be used.").

16. See Jeffrey Q. Smith \& Grant R. MacQueen, Going, Going, But Not Quite Gone: Trials Continue to Decline in Federal and State Courts. Does it Matter?, 101 JudicAture 26, 28 (2017) (depicting a notable decline in federal jury trials from 2000 to 2015).

17. See Letter from Harold Kim, Chief Operating Officer, U.S. Chamber Inst. Legal Reform, to Jerrold Nadler, Chairman, U.S. House of Representatives Comm. on Judiciary, and Doug Collins, Ranking Member, U.S. House of Representatives Comm. on Judiciary (Sept. 10, 2019), https://www.uschamber.com/sites/default/files/ 
bargaining makes trial by jury a rarity invoked by only the least rational defendants - those willing to reject a much more favorable offer from the prosecutor who holds near-total power over what crimes to charge and what sentences to recommend. ${ }^{18}$ On the civil side, advocated "reforms" include sending even more cases to arbitration ${ }^{19}$ or summarily adjudicating them before trial. ${ }^{20}$ Even after jury trials, judges sometimes flip outcomes or impose damage caps that contradict the jury's determinations. ${ }^{21}$

Much dissatisfaction with civil juries stems from executives who fear that juries empower the public to hold business accountable. ${ }^{22}$ But, of

190910_h.r._1423_fairact_housejudiciary.pdf [https://perma.cc/22QC-5C2N] (advocating against the Forced Arbitration Injustice Repeal ("FAIR") Act); Gene Schaerr \& Jed Brinton, Business and Jury Trials: The Framers' Vision Versus Modern Reality, 71 Оніо Sт. L.J. 1055, 1056 (2010) (arguing that "at least [90\%]" of the general counsel of Fortune 500 companies "would [if possible] vote to abolish the right to jury trial"); Judson Phillips, Trump Tort Reform Threatens the 7th Amendment, Wash. Times (Mar. 2, 2017), https://www.washingtontimes.com/news/2017/mar/2/trump-tort-reform-threatens-7th-amendment/ [https://perma.cc/92HR-QTNQ] (arguing that the tort-reform movement threatens jury trials).

18. See Megan S. Wright, Shima Baradaran Baughman \& Christopher T. Robertson, Inside the Black Box of Prosecutor Discretion, U.C. DAVIs L. REV. (forthcoming 2022); Christopher Slobogin, Plea Bargaining and the Substantive and Procedural Goals of Criminal Justice: From Retribution and Adversarialism to Preventive Justice and Hybrid-Inquisitorialism, 57 WM. \& MARY L. Rev. 1505, 1516-17 (2016).

19. See AT\&T Mobility LLC v. Concepcion, 563 U.S. 333, 345-46 (2011) (describing the Federal Arbitration Act and noting the "national policy" in favor of arbitration agreements (citation omitted)). But see Sevier Cnty. Schs. Fed. Credit Union v. Branch Banking \& Tr. Co., 990 F.3d 470, 481 (6th Cir. 2021) (finding an arbitration agreement invalid on narrow grounds); Jean R. Sternlight, The Rise and Spread of Mandatory Arbitration as a Substitute for the Jury Trial, 38 U.S.F. L. ReV. 17, 17 (2003) (discussing how most "lawyers, courts, and commentators have failed to adequately consider constitutional rights to a jury trial in determining the validity of arbitration clauses").

20. See Suja A. Thomas, What Happened to the American Jury?: Proposals for Revamping Plea Bargaining and Summary Judgment, 43 Litig. 25, 29-30 (2017); see also Sarah Sachs, The Jury Is out: Mandating Pre-Treatment Arbitration Clauses in Patient Intake Contracts, 2018 J. DisP. Resol. 117, 117 (2018) (noting how most patients do not understand that they are signing away "their right to a jury trial or judicial oversight of their disputes" after signing patient intake forms).

21. E.g., Saccameno v. U.S. Bank Nat'l Ass'n, 943 F.3d 1071, 1088, 1091 (7th Cir. 2019) (reducing punitive damages to approximately one-fifth what the jury awarded); see also George L. Priest, Introduction to Cass R. Sunstein et Al., Punitive DamAGEs: How Juries Decide 4 (2002).

22. Young, supra note 15, at 76. Said Young:

[I]t is fair to observe that for decades, business and insurance interests have disparaged our civil juries while the courts have failed to defend the single institution upon which their moral authority ultimately depends. As a result, ... bipartisan majorities ... have restricted access to the ... jury severely.

Id: see also Neil Vidmar \& Valerie P. Hans, American Juries: The Verdict 341 (2007) (finding that juries hold corporate actors liable "because of their greater knowledge, resources, and potential for impact"). 
course, that is a key reason for their existence. ${ }^{23}$ Since the delegates to the Constitutional Convention were, "for the most part, creditor-oriented nationalists," they may have intentionally omitted a civil jury right, which is populist and potentially favors debtors. ${ }^{24}$ "The omission of the civil jury triggered a firestorm of protest." ${ }^{25}$ To ensure that the judiciary served the economic interests of the many, anti-federalists insisted on the inclusion of the Seventh Amendment and related provisions in the Judiciary Act of $1789 .{ }^{26}$ The criminal jury right has a similarly populist bent. ${ }^{27}$

Of course, some oppose jury trials for good-faith reasons. Given the small number of jurors on any panel, their decisions can be fairly criticized as being almost as unpredictable as a lottery. ${ }^{28}$ As currently constituted, juries are demographically unrepresentative-largely due to ethnic, racial, and class-based disparities-frustrating the ideal of judgment by one's peers. ${ }^{29}$ Relatedly, most Americans view compulsory jury service as a huge imposition, especially when it conflicts with personal and professional obligations. ${ }^{30}$ Even within the legal profession, overworked lawyers and judges often prefer quick and certain pleas or settlements to lengthy and uncertain jury trials. ${ }^{31}$ The

23. Paul D. Carrington, The Civil Jury and American Democracy, 13 Duke J. COMPAR. \& INT'L L. 79, 84 (2003) ("It is generally assumed, and not without reason, that juries are prone to favor civil litigants who are members of the community whom they represent.").

24. Stephan Landsman, The Civil Jury in America: Scenes from an Unappreciated History, 44 Hastings L.J. 579, 597 (1993) (internal citation omitted).

25. Id. at 598.

26. See generally Charles Warren, New Light on the History of the Federal Judiciary Act of 1789, 37 Harv. L. Rev. 49, 96-114 (1923).

27. See Duncan v. Louisiana, 391 U.S. 145, 156 (1968) ("Providing an accused with the right to be tried by a jury of his peers gave him an inestimable safeguard against the corrupt or overzealous prosecutor and against the compliant, biased, or eccentric judge.").

28. See Kevin M. Clermont \& Theodore Eisenberg, Trial by Jury or Judge: Transcending Empiricism, 77 CORNELL L. Rev. 1124, 1125 (1992) (collecting critiques of juries); see also Valerie P. Hans \& Theodore Eisenberg, The Predictability of Juries, 60 DePaul L. Rev. 375, 375 (2011) ("The jury is said to be the least predictable of the decision makers in the legal system.").

29. See Hiroshi Fukurai, Edgar W. Butler \& Richard Krooth, Race and The Jury 3-4 (James Alan Fox \& Joseph Weis eds., 1993); Rob Walters, Michael Marin \& Mark Curriden, Are We Getting a Jury of Our Peers?, 68 Tex. BAR J. 144, 145-46 (2005).

30. See Butler v. Perry, 240 U.S. 328, 332-33 (1916) (noting that the Thirteenth Amendment does not bar "enforcement of those duties [that] individuals owe to the state, such as services in the army, militia, [or] the jury"); Andrew J. Bloeser, Carl McCurley \& Jeffery J. Mondak, Jury Service as Civic Engagement: Determinants of Jury Summons Compliance, 40 Am. Pol. Rsch. 179, 184-85 (2012); Thomas L. Fowler, Filling the Box: Responding to Jury Duty Avoidance, 23 N.C. CENT. L.J. 1, 1 nn. 4-5 (1997).

31. Christopher Slobogin, The Case for a Federal Criminal Court System (and Sentencing Reform), 108 CALIF. L. REv. 941, 942 (2020) (noting that "the number of criminal and prisoner cases commenced in federal court has far outpaced increases in judgeships"); Darryl K. Brown, Essay, The Perverse Effects of Efficiency in Criminal 
coronavirus pandemic only heightened concerns about jury trials, which entail convening six to twelve jurors in an enclosed space before having them deliberate for hours, days, or even longer. ${ }^{32}$

Indeed, juries can be inefficient and unpredictable. Rather than abolishing or cabining them, however, we should reinvent them so that they better serve their original purposes of fostering democratic engagement and epistemic legitimacy.

Compare the carriages, bridges, and ships used for war and transport in 1789 with technologies used for such purposes today. The changes are profound. Scientific and technological advances revolutionized warfare and transportation; in doing so, they made both endeavors more convenient, more efficient, and more effective. Yet aside from admitting a broader franchise of citizens, today's juries scarcely differ from their seventeenth- and eighteenth-century counterparts. ${ }^{33}$ Given this stagnancy, it is unsurprising that the jury trial is not optimally adapted to modernity. The warships that Thomas Jefferson ordered to bombard the Barbary Pirates would not be able to fulfill their purpose accurately or efficiently today, either.

Scientific advances, combined with the ever-increasing ease of longdistance communication, make one wonder what the jury would resemble if it had been invented in 2021. Given the rise of applied statistics and findings from political psychology, behavioral economics, neuroscience, and other fields, would we stick to twelve or fewer jurors? Would we allow lawyers to handpick some jurors to remove "peremptorily" out of sheer intuition or prejudice? Would we force jurors to sit through live, synchronous trials lasting days, weeks, or even months? Would we continue hoping that, when exposed to inadmissible evidence, merely instructing jurors to ignore that evidence will cure or eliminate prejudice? Given the proliferation of inexpensive computers and the Internet, would we even require jurors to physically assemble at courthouses? Would we conduct civil trials of national importance, involving issues like patent infringement or product liability, with juries chosen from local venires? Would we still have jurors deliberate in secret, often by way of personal anecdotes and racialized and gendered rhetoric that would have been utterly inadmissible at trial? In hindsight, the jury trial of 1789 seems, at best, quaint - and, at worst, counterproductive.

It turns out that these familiar features of the jury are not essential; they are historical contingencies reflecting eighteenth-century scien-

Process, 100 VA. L. REv. 183, 183-84 (2014) ("The number of cases that courts must resolve has grown relentlessly for decades, and the public infrastructure has not kept pace."); see also Arthur R. Miller, The Pretrial Rush to Judgment: Are the "Litigation Explosion," "Liability Crisis," and Efficiency Clichés Eroding Our Day in Court and Jury Trial Commitments?, 78 N.Y.U. L. REV. 982, 1098 (2003).

32. See infra Part II.

33. See generally Douglas G. Smith, The Historical and Constitutional Contexts of Jury Reform, 25 Hofstra L. REv. 377, 377-79 (1996). 
tific and technological realities. ${ }^{34}$ Scholars have suggested moderate reforms. ${ }^{35}$ We believe that a more fundamental reckoning is in order.

This Article proceeds in three parts. The first Part discusses the effects of the coronavirus ("COVID-19") pandemic on the judiciary throughout 2020 and 2021. We show that many of our proposed reforms are no longer speculative but were wholly or partly implemented in real cases. We also discuss coronavirus-era caselaw with implications for the constitutionality (or lack thereof) of online trials. The second Part articulates six fundamental reforms aimed at bringing juries into the twenty-first century. These include: (1) increasing the number of randomly selected jurors and eliminating peremptory challenges; (2) increasing the use of video presentations; (3) shortening and reorganizing trial presentations; (4) divorcing trials from classic time and place restrictions; (5) creating nationwide jury pools for national cases (and expanding criminal pools to the extent that the Constitution permits); and (6) aggregating votes that individual jurors cast, thereby discarding interpersonal "deliberation" entirely. The third and final Part briefly reviews whether courts are likely to hold these reforms constitutional before gesturing toward several necessary changes to the rules of civil and criminal procedure.

\section{Online Judicial Proceedings in 2020 \& 2021}

The COVID-19 pandemic has left no institution untouched. Thus far, the institutions that survived-and that may even thrive when the crisis ends-are those that have adapted.

In this Part, we review the judiciary's response to the pandemic while also detailing attempts by state and local governments and academic institutions to brainstorm "best practices" for online trials. We also detail constitutional concerns in the criminal context to argue that-when pandemics like COVID-19 surpass one year-online trials may be constitutionally necessary if defendants' speedy-trial rights are to be respected.

34. See, e.g., Williams v. Florida, 399 U.S. 78, 102-03 (1970) ("[T]he fact that the jury at common law was composed of precisely 12 is a historical accident, unnecessary to effect the purposes of the jury system and wholly without significance ...." (citing Duncan v. Louisiana, 391 U.S. 145, 182 (1968) (Harlan, J., dissenting))); see also Ian Ayres, Pregnant with Embarrassments: An Incomplete Theory of the Seventh Amendment, 26 VAL. L. REV. 385, 387-89 (1991) (arguing that a significant typo-a conspicuous comma-in the Seventh Amendment indicates that the Framers' text is fallible).

35. See, e.g., Akhil Reed Amar, Reinventing Juries: Ten Suggested Reforms, 28 U.C. Davis L. Rev. 1169, 1178, 1184 (1995) (suggesting that when called for jury duty, courts should not excuse people claiming to be burdened by service and arguing that "more trials can take place if we get rid of all the wasteful preliminaries like elaborate voir dire"). 


\section{A. COVID-19's Effect on Civil Trials}

The first federal plan for safeguarding a functioning judiciary in the event of a pandemic was published in April 2007 when the Department of Justice released a report entitled Guidelines for Pandemic Emergency Preparedness Planning: A Road Map for Courts ("Roadmap"). ${ }^{36}$ The Roadmap, which is far more useful logistically than legally, provided federally supported guidelines to state and local courts detailing step-by-step, so-called "best practices" for pandemicresponse plans. ${ }^{37}$ The document presciently acknowledged that, in the case of a prolonged pandemic, adopting a greater embrace of the Internet will be not only useful but "needed to continue operations." 38 Despite mentioning the necessity of increasing courts' teleconferencing abilities and writing that courts should "review alternative court sites and other means by which to communicate with ... participants," the authors did not conduct an in-depth analysis on the concept of online jury or bench trials. ${ }^{39}$

When the pandemic struck in 2020, courts, schools, and employers adapted first, moving lessons online and asking (or demanding) that non-essential employees work from home. Federal and state legislatures were close behind. On May 15, 2020, only two months after journalists wondered whether a "virtual Congress is possible," 40 Congress answered in the affirmative. ${ }^{41}$ This was no small change. Per the New York Times, "the coronavirus pandemic officially succeeded" where the 1793 Philadelphia yellow fever and 1918 Spanish influenza outbreaks, September 11, 2001, attacks, and "generations of agitators for

36. See Crim. Cts. Tech. Assistance Project, Guidelines for Pandemic Emergency Preparedness Planning: A Road Map for Courts, Bureau Just. Assistance 1 (Apr. 2007), https://bja.ojp.gov/sites/g/files/xyckuh186/files/Publications/Pandemic_Road_Map.pdf [https://perma.cc/HH3Q-NJDC] ("[I]t is vital to develop a structured plan for preparing the courts to cope with a pandemic outbreak.").

37. Id. at 14-15 ("[E]xisting legal authority relating to public health matters should be analyzed to ensure there is adequate legal foundation for any court actions. The planning process should include the following key components: [(1)] [f]ormation of a planning committee[,] . . [ [(2)] [r] eview of constitutional provisions and pertinent authority under state law and [appropriate] regulations[,] ... [and (3)] [c]onsideration of technological and other capabilities ...." (emphasis added)).

38. Id. (emphasis added).

39. See id. at 11. Although not comprehensive, the Roadmap did discuss ways to preserve public access to courts. Id. ("Employing technology such as televised court proceedings, public access to computerized information systems, and simultaneous court transcription to provide participants and the public access to court proceedings may help remedy this issue.").

40. Evan Halper \& Jennifer Haberkorn, Congress May Move Online as Members Become Sick, Quarantined, GovernING (Mar. 20, 2020), https://www.governing.com/ now/Congress-May-Move-Online-as-Members-Become-Sick-Quarantined.html [https://perma.cc/G2R3-6X9R].

41. Nicholas Fandos, With Move to Remote Voting, House Alters What It Means for Congress to Meet, N.Y. TIMEs (May 15, 2020), https://www.nytimes.com/2020/05/ 15/us/politics/remote-voting-house-coronavirus.html [https://perma.cc/CVQ9-AV4P]. 
institutional change" failed-it untethered "Congress from its mandate to come together physically." 42

If legislators can move online, why not judges? And if legislators can make law online, and judges can interpret law online, why should jurors be incapable of applying law online?

With its reliance on arguments from authority and its reverence for precedent, the judiciary can sometimes seem particularly traditionalist. ${ }^{43}$ This may partly explain why some state judiciaries took surprisingly long to meaningfully respond to the pandemic. ${ }^{44}$ For example, the Supreme Court of Arkansas did not suspend or otherwise substantially alter jury trials until November $20,2020 .{ }^{45}$ This delay occurred even though the Governor had announced a state of emergency on March 11, 2020, ${ }^{46}$ only two days before President Trump declared a national emergency. ${ }^{47}$

Still, many courts were more aggressive in trying to move as much business as possible from the courthouse to the Internet. Although some courthouses successfully configured their courtrooms to comply with the CDC's social-distancing guidelines, many courts found that their facilities simply could not be physically reconfigured in a manner enabling safe jury trials. ${ }^{48}$ Even if it were possible to physically reconfigure every courthouse, doing so might be cost prohibitive. ${ }^{49}$ Even courts that were initially reluctant to do so therefore found themselves moving several functions online.

42. $I d$.

43. E.g., Brad Taylor, Law in the Time of Covid-19: Looking Backward While Moving Forward, 108 ILL. BAR J. 26, 26 (2020) ("The legal profession is, out of necessity, practicality, or sometimes sheer stubbornness, notoriously backward looking."); see also James E. Moliterno, The American Legal Profession in Crisis 215 (2013) ("In short, the legal profession is ponderous, backward looking, and selfpreservationist.").

44. See generally COVID-19 Roundup: Court Closures and Procedural Changes, Westlaw (Apr. 30, 2020), 2020 WL 1223450 (detailing information updated as of April 2020 about court closures and procedural changes, including several instances in which courts extended court shut-downs long after first anticipated).

45. In re Response to the COVID-19 Pandemic, 2020 WL 6817802, at *1-3 (Ark. Nov. 20, 2020).

46. Id. at $* 1$.

47. Andrew S. Boutros, Jay R. Schleppenbach \& Gregory T. Noorigian, The Collision of the Speedy Trial Clock with the Coronavirus's Slowdown Realities: Justice in the Time of COVID-19, Crim. Just. Mag., Oct. 26, 2020, at 49.

48. Herbert B. Dixon, Jr., Pandemic Potpourri: The Legal Profession's Rediscovery of Teleconferencing, 59 JudGes' J. 37, 38 (2020).

49. Boutros et al., supra note 47, at 49, 53 (writing that despite an August 2020 felony trial in the Northern District of Illinois, "it remains to be seen whether the intense precautions taken there, which applied to every aspect of the juror's experience from parking to security to deliberations, can be replicated on a widespread basis"). 
The first such judicial proceedings were generally pre-trial hearings and depositions. ${ }^{50}$ On March 31, 2020, the Judicial Conference temporarily "approved ... video and teleconferencing for certain criminal and civil proceedings." 51 Importantly, "[t]his approval also" authorized judges to use "teleconferencing to provide the public and media audio access to court proceedings." 52 The Judicial Conference's action followed the March 27, 2020, passage of the Coronavirus Aid, Relief, and Economic Security ("CARES") Act, which temporarily expanded video- and telephone conferencing for certain judicial proceedings. ${ }^{53}$ The CARES Act's passage prompted states to increase the use of videoconferencing in court proceedings. ${ }^{54}$ Not coincidently, then, March 2020 marked a turning point after which courts increasingly pondered the logistics of holding trials and hearings online for the remainder of the pandemic.

Although courts were hesitant to conduct actual trials online, the idea was not altogether new, having been discussed in law review articles in 2006 and, briefly, in $1994 .{ }^{55}$ That said, most pre-coronavirus scholarship focused on hearings, depositions, and other functions that involve judges and attorneys but not jurors.

In June 2020, NYU Law's Civil Jury Project enlisted dozens of judges, academics, and practitioners to craft protocols intended for online civil jury trials; it then tested the protocols in a mock trial. ${ }^{56}$ The three protocols detailed best practices for online (1) jury selection, (2) trial, and (3) deliberation. ${ }^{57}$ The participants generally concluded that, while challenging, online civil jury trials are viable if reasonable precautions are undertaken. ${ }^{58}$ The mock trial remains

50. See, e.g., Sonrai Sys., LLC v. Romano, No. 16 CV 3371, 2020 WL 3960441, at *3 (N.D. Ill. July 13, 2020) (COVID-19 "health concerns . . . create[d] 'good cause' for the entry of an order requiring that Geotab's experts' depositions take place by remote videoconference.”); SAPS, LLC v. EZCare Clinic, Inc., No. 19-11229, 2020 WL 1923146, at *2 (E.D. La. Apr. 21, 2020) ("This court will not require parties to appear in person . . . in the midst of the present pandemic.").

51. Dixon, supra note 48 , at 38.

52. $I d$.

53. Id.

54. Id.

55. Nancy S. Marder, Cyberjuries: A New Role as Online Mock Juries, 38 U. ToL. L. REV. 239, 239 (2006) ("[O]nline juries . . could offer online group decision-making by laypersons in cases that do not require a traditional jury trial."); Henry H. Perritt Jr., Changing Litigation with Science and Technology: Video Depositions, Transcripts and Trials, 43 EmORY L.J. 1071, 1071-72 (1994) (suggesting the concept); see also Bernard Chao, Christopher Robertson \& David Yokum, Crowdsourcing \& Data Analytics: The New Settlement Tools, 102 Judicature 62, 63 (2018) (arguing for online mock juries as an alternative to trials).

56. See Virtual Jury Trial Protocols, Civ. Jury Project (2021), https:// civiljuryproject.law.nyu.edu/resources-2/protocols/ [https://perma.cc/X4QS-SSNP].

57. Id.

58. See, e.g., Michael Shammas, The Verdict Is in: Online Jury Trials Are Possible, Civ. Jury Project, https://civiljuryproject.law.nyu.edu/the-verdict-is-in-online-jurytrials-are-possible/ [https://perma.cc/JN88-GKQF] (proposing "mixed" trials during 
available on YouTube, ${ }^{59}$ and major libraries have developed repositories of relevant materials. ${ }^{60}$

Several jurisdictions began proposing their own protocols. The Yolo County Superior Court of California promulgated exemplary guidelines for jurors and attorneys aimed at minimizing the risk of spreading infectious diseases. ${ }^{61}$ The county effectively determined that only proceedings (e.g., jury deliberations in their view) that cannot be constitutionally, practically, or confidentially completed via videoconferencing should be conducted inside courthouses with social-distancing safeguards like spaced seating. ${ }^{62}$ Other jurisdictions soon followed, with some-like Illinois-citing the Civil Jury Project's protocols. ${ }^{63}$

An Alabama district court set a trial date of June 1, 2020, in what "was set to be the first federal civil [jury] trial in the country after courts closed for the coronavirus pandemic." 64 The court eventually concluded on its own motion that a continuance to limit the virus's spread was warranted while nonetheless emphasizing that "[j]ury trials cannot remain stalled indefinitely." 65 In an order staying trials, likewise, California's Chief Justice noted that "[c]ourts may conduct such a trial at an [another] date, upon a finding of good cause shown or through the use of remote technology." 66

The first COVID-19 online trial was a bench trial (without a jury) held on April 22, 2020, when a Harris County, Texas judge oversaw a one-day trial over the Zoom videoconferencing platform. ${ }^{67}$ Despite its

the pandemic to preserve confidentiality with some portions held online and other portions - such as confidential jury deliberations-held in socially spaced courtrooms) [hereinafter Online Jury Trials Are Possible].

59. Civ. Jury Project, Highlights from the Civil Jury Project at NYU School of Law and CCCPC Virtual Mock Trial, YouTube (July 21, 2020), https://www.youtube.com/ watch?v=7U_aVbklGpU\&feature=YOutu.be. [https://perma.cc/ZQF3-22DJ].

60. See, e.g., Robin Gardner, Annotated Bibliography of Covid-19 Legal Literature, U. Melb. L. Sch. LiBr. (Oct. 26, 2020), https://law.unimelb.edu.au/_data/assets/ pdf_file/0008/3522437/MLS-COVID-19-Legal-Scholarship-Bibliography-Consolidation-26Oct2020.pdf [https://perma.cc/ZWL2-D5X6] (providing Australian, Canadian, British, and American scholarship on reconciling common law procedures with COVID-19).

61. See Online Jury Trials Are Possible, supra note 58.

62. $I d$.

63. Court Operations During COVID-19 Task Force: Guidelines on Remote Jury Selection in Civil Trials, ILL. CTS. 2, https://courts.illinois.gov/CircuitCourt/Jury/Remote/Remote_Jury_Selection_Guidelines.pdfv [https://perma.cc/Y7ZA-FU7J].

64. See Quinn v. City of Tuskegee, 464 F. Supp. 3d 1262, 1263 (M.D. Ala. 2020).

65. Id.

66. Judicial Council of California Statewide Emergency Order by Hon. Tani G. Cantil-Sakauye, Chief Justice of California and Chair of the Judicial Council, LACOURT.ORG (Mar. 30, 2020), http://www.lacourt.org/newsmedia/uploads/14202043 1048StatewideOrderbytheChiefJustice-ChairoftheJudicialCouncil03-30-2020.pdf [https://perma.cc/4D8P-S5J9].

67. Daniel Siegal, Texas Court Pioneers Trial by Zoom in Atty Fee Dispute, LAw360 (Apr. 22, 2020, 10:05 PM), https://www.law360.com/articles/1265459/texascourt-pioneers-trial-by-zoom-in-atty-fee-dispute [https://perma.cc/8SNX-BRZX]. 
relatively boring subject matter (attorneys' fees), the case garnered substantial interest. ${ }^{68}$ Approximately 2,000 viewers tuned in. ${ }^{69}$

The nation's first pandemic-era online civil jury trial was held in Texas state court on May 18, 2020. ${ }^{70}$ Although the verdict was nonbinding ${ }^{71}$ the trial was nonetheless notable because of how relatively smoothly it went, thereby proving the concept. Texas blazed another path when, in August 2020, a "virtual jury trial . . brought about by the pandemic" was conducted by a state criminal court in Travis County, Texas. ${ }^{72}$ Watched by approximately 1,000 viewers, the case involved "misdemeanor charges alleging excessive speed in a construction zone," and-after using a "private virtual room to review the evidence and deliberate"- the jury returned verdicts of guilty on the speeding charge and not-guilty on the work-zone enhancement charge. ${ }^{73}$ A third online jury trial soon followed, this time in a federal civil court in Seattle, Washington, yielding a $\$ 1.35$ million verdict. ${ }^{74}$

Griffin v. Albanese Enterprise, Inc. has been called "the nation's first ... fully remote, state court civil jury trial" with a binding verdict. ${ }^{75}$ Florida jurors awarded the plaintiff more than $\$ 300,000$ in damages for a beating suffered at the hands of bouncers in a Jacksonville, Florida, club. ${ }^{76}$ The court conducted jury selection entirely online, and the one-day trial remains digitally available for study by scholars, lawyers, and judges. ${ }^{77}$

68. Id.

69. Id.

70. See Nate Raymond, Texas Tries a Pandemic First: A Jury Trial by Zoom, Reuters (May 18, 2020, 6:19 AM), https://reut.rs/3hKVqCs [https://perma.cc/J3H66496]. The verdict was non-binding. $I d$.

71. Id. ("[T]he abbreviated format and non-binding verdict make it ideal to test the viability of holding jury trials remotely, as they grapple with the more daunting challenge of how to conduct them safely in person during the pandemic.").

72. Dixon, supra note 48, at 38.

73. See id. "Prosecutors and defense attorneys posted exhibits using the file-sharing service Box. The defendant's counsel used a virtual breakout room to confer with their client." Id. (internal citation omitted).

74. $I d$.

75. Arlin Crisco, $\$ 354 K+$ Verdict Wraps Landmark Remote Jury Trial Over Woman's Beating at Florida Club, Courtroom View Network (Aug. 11, 2020, 2:25 PM), https://blog.cvn.com/354k-verdict-wraps-landmark-remote-jury-trial-overwomans-beating-at-florida-club [https://perma.cc/M6H9-67UA] (emphasis added); see also Kevin-Khristián Cosgriff Hernández, Key Takeaways from Groundbreaking Virtual Civil Jury Trial, Law360 (Oct. 8, 2020, 12:30 PM), https://www.law360.com/ip/ articles/1317417?utm_source=RSs\&utm_medium $=$ RSs\&utm_campaign=Section [https://perma.cc/K888-AU5F].

76. See sources cited supra note 75.

77. Cayla Griffin vs. Albanese Enterprise, Inc., Courtroom View Network, https://pages.cvn.com/duval-county-florida-remote-trial-program [https://perma.cc/ ERD9-VMEL]; see also Justin Jouvenal, Justice by Zoom: Frozen Video, a Cat - and Finally a Verdict, WASH. PosT, https://www.washingtonpost.com/local/legal-issues/jus tice-by-zoom-frozen-video-a-cat - and-finally-a-verdict/2020/08/12/3e073c56-dbd3-

11ea-8051-d5f887d73381_story.html (Aug. 12, 2020, 5:19 PM) [https://perma.cc/V9R52DDZ]. 


\section{B. Criminal Trials \& the Speedy-Trial Guarantee}

The criminal justice system saw particularly disruptive challenges due to COVID-19. Jurisdictions altered their usual criminal practice in several ways, including, namely: tolling statutes of limitations, ${ }^{78}$ releasing inmates early through parole or compassionate-release programs,${ }^{79}$ and limiting visitation to prisons and jails. ${ }^{80}$ State and federal appellate courts also began hearing criminal and civil oral arguments via audio or video. ${ }^{81}$

In trial courts, the coronavirus's impact has varied according to the severity of crimes charged and the stage of proceedings. "At one extreme, a wide range of constitutional rights are implicated at a criminal trial; and for that reason, no online felony trial has been conducted. At the other, at least one misdemeanor trial and several pre-trial proceedings, as well as appellate and post-conviction proceedings, have been conducted online." 82 The Internet worked especially well for "proceedings like first appearances and plea colloquies, which consist of the bulk of caseloads." 83

Juries were of particular concern. Courts moved quickly to allow grand juries to deliberate online especially after the Southern District of New York, citing the Federal Rules of Criminal Procedure, did so. ${ }^{84}$ More controversially, a federal judge permitted a juror, during the live courtroom trial of an Iranian banker, to deliberate "by FaceTime because the juror reported feeling unwell. In light of coronavirus concerns, [the judge] stated the court was under 'extraordinary circumstances' and in 'untested waters.' After being assured the juror

78. See, e.g., COVID-19 and the Criminal Justice System: A Guide for State Lawmakers, NAT'L Conf. St. Legislators (Aug. 19, 2020), https://www.ncsl.org/research/civil-and-criminal-justice/covid-19-and-the-criminal-justice-system-a-guide-forstate-lawmakers.aspx [https://perma.cc/5758-K9TD] ("Ohio's legislature enacted a law tolling statutes of limitations for criminal offenses, civil actions and administrative actions . . . set to expire between March 9, 2020[,] and July 30, 2020.”).

79. See id.

80. Id. ("At least [seventeen] states and Washington, D.C., suspended all visitation[,] and the remaining [thirty-three] states suspended normal visitation while allowing visits with attorneys.").

81. Id. "In the beginning of the pandemic, the U.S. Supreme Court postponed oral arguments and held oral arguments by telephone, making live audio of the arguments available to the public for the first time ever." Id. In addition, Kansas allowed "the use of two-way electronic audio-visual communication in court proceedings." Id.

82. Deniz Ariturk, William E. Crozier \& Brandon L. Garrett, Virtual Criminal Courts, U. Chi. L. Rev. OnLine (Nov. 15, 2020), https://lawreviewblog.uchicago.edu/ 2020/11/16/covid-ariturk/ [https://perma.cc/GF6E-EX2C].

83. Id.

84. See Pete Brush, Grand Jurors in SDNY Get Video Option Amid Virus Outbreak, LAw360 (Mar. 21, 2020, 4:59 PM), https://www.law360.com/articles/1255774/ grand-jurors-in-sdny-get-video-option-amid-virus-outbreak [https://perma.cc/CUV3BBHR]; see also FED. R. CRIM. P. 6 (not requiring physical presence). 
would be secluded in [an] apartment, [the judge] stated to the juror, 'You must think of yourself as present in the jury room.'" 85

For criminal trials, the pandemic created a double bind. On one hand, the speedy-trial guarantee presses courts to use video if necessary to clear cases, but the Confrontation Clause arguably suggests that only physical trials can pass constitutional muster. ${ }^{86}$ In 2020 , defense attorneys began questioning "how much delay is too much for the speedy-trial right, even when dealing with a global pandemic." 87 Concerned about speedy-trial rights, some emphasized "the need for solutions like video[]conferencing to avoid delay, if doing so is in their clients' interests." 88 Unfortunately, the March 2020 CARES Act merely signaled that videoconferencing is permitted; it did not say when it is allowed; nor did it "provide instructions, much less guidance, on defendants' speedy-trial rights." 89

Since the "Constitution does not specifically define what it means for a trial to be "speedy," speedy-trial timelines were initially determined state by state..$^{90}$ But in 1974, Congress passed the Speedy Trial Act $^{91}$ to promote jurisdictional uniformity. "Interestingly, the Act's proponents did not focus solely on the rights of individual defendants, but also on a perceived need to obtain convictions quickly to reduce the risks of recidivism." ${ }^{92}$ As a result, although the Sixth Amendment's speedy-trial provisions relate to defendant-oriented due process concerns, the statutory framework has a broader focus.

That framework establishes concrete time limits to complete federal criminal prosecutions. For instance, absent court-approved extensions, the period between arrest and indictment usually cannot exceed thirty days while that between arraignment and trial cannot surpass seventy. ${ }^{93}$ If these limits are violated, then absent a recognized exclusion, "the complaint may be dismissed with or without prejudice depending

85. Richard Gabriel, What Online Jury Trials Could Look Like, Law360 (Mar. 26, 2020, 2:56 PM), https://www.law360.com/articles/1257185/what-online-jury-trialscould-look-like [https://perma.cc/BKN5-TDVZ].

86. See, e.g., Brandon Marc Draper, Essay, And Justice for None: How COVID-19 Is Crippling the Criminal Jury Right, 62 B.C. L. Rev. E-Supplement I.-1, I.-3 (2020) (arguing that jury trial by video conference would be "inherently unconstitutional" in nature but acknowledging that it could be necessary to use such trials, at least when defendants consent, because of speedy-trial concerns).

87. Boutros et al., supra note 47, at 48; accord John Eric Rapp \& Ben Bigham, COVID-19 v. Criminal Defendants, 89 J. KAN. BAR Ass'n 32, 32-33 (2020).

88. Boutros et al., supra note 47 , at 54 .

89. Id. at 51.

90. Id.; see also Cal. Penal Code $§ 1382$ (West 2010); 725 Ill. Comp. Stat. Ann. 5 / 103-5 (West 2014).

91. See 18 U.S.C. $\$ 3161$ (2008).

92. Boutros et al., supra note 47, at 50 (citing H.R. REP. No. 93-1508, at 8, 11 (1974)).

93. 18 U.S.C. $§ 3161(b)-(c)$. 
upon the seriousness of the offense, the facts and circumstances that led to the dismissal, and the impact of re-prosecution." 94

Federal courts have generally handled delays by invoking the "[j]udicial emergency and implementation" provision of an obscure 1975 statute. ${ }^{95}$ Under the statute, the chief judge of any judicial district may request from the judicial council of her circuit up to a oneyear suspension of the Speedy Trial Act on grounds that the court is "unable to comply ... due to the status of its court calendars." 96 What constitutes a "judicial emergency" 97 has never been clearly defined. The Ninth Circuit nonetheless relied on the statute to approve the COVID-19-related continuances imposed by three-fourths of California's federal districts.

Courts frequently invoke the "ends of justice" as a basis for excluding time under the Speedy Trial Act. ${ }^{98}$ When conducting the $\S 3161(\mathrm{~h})(7)(\mathrm{A})$ analysis, a court must explicitly provide its justifications before granting a continuance. ${ }^{99}$ A continuance is never granted merely "because of general congestion of the court's calendar, lack of diligent preparation," or the government's "failure to obtain available witnesses." 100

Although courts have thus far treated coronavirus-era "litigation continuances-even in criminal cases-as presumptively valid," the same may not "hold true three, six, nine, [twelve], [eighteen], or [twenty-four] months from now." ${ }^{101}$ Colorado's Supreme Court has "already recognized that blanket continuances without individualized fact-finding offend speedy-trial rules." 102 Ultimately, "it remains to be seen just how much delay can be tolerated under the Sixth Amendment and the Speedy Trial Act." 103 Absent widespread online trials, courts may be forced to triage cases in a manner wherein "only the most serious felony cases involving dangerous defendants who are detained pretrial and refuse to waive speedy trial deadlines [are] tried." 104

Defendants have also raised unsuccessful Fifth and Fourteenth Amendment due process objections to pandemic-era trials. ${ }^{105} \mathrm{Re}$ search showed that "three out of four jurors" were "nervous about

94. See Boutros et al., supra note 49, at 50; see also 18 U.S.C. § 3162(a)(1)-(2).

95. 18 U.S.C. $\S 3174($ a).

96. $I d$.

97. Id.

98. 18 U.S.C. $\S 3161(\mathrm{~h})(7)(\mathrm{A})$.

99. Id.; see also id. $\S 3161(\mathrm{~h})(7)(\mathrm{B})$ (listing statutory factors).

100. $I d . \S 3161(\mathrm{~h})(7)(\mathrm{C})$.

101. Boutros et al., supra note 47 , at $54-55$.

102. Id. at $53-54$.

103. Id. at 54 .

104. See Melanie Wilson, The Pandemic Juror, 77 Wash. \& Lee L. Rev. Online 65, 96 (2020).

105. See, e.g., United States v. Dermen, 452 F. Supp. 3d 1259, 1264 (D. Utah 2020) (finding that the defendant failed to establish the "manifest necessity" required by the 
attending a trial," and the heterogeneity of such concerns may skew jury pools because "people of color, Democrats, and older Americans [were] very concerned about contracting the virus."106

Some have also suggested that especially long delays during pandemics could violate the Eighth Amendment's prohibition against cruel and unusual punishments-like when a defendant's jail has an especially high virus transmission rate. ${ }^{107}$

Defendants also objected to modified trial procedures, largely unsuccessfully. For example, when one court imposed masking and social distancing requirements during jury selection, an intermediate Pennsylvania appellate court concluded that "the trial court did not abuse its discretion" or violate "the essential demands of fairness." 108 Adopting a largely functionalist approach, the appeals court noted that "the trial court indicated . . . that it was able to adequately assess the prospective jurors' answers during voir dire so as to determine . . . whether to disqualify a prospective juror." ${ }^{109}$ Notably, the same standard applies to the constitutionality of modified jury proceedings during voir dire as to other stages of the trial, such as "the guilt and sentencing phases." 110

The United States District Court for the Northern District of Illinois held a two-week, in-person jury trial in September 2020 featuring two defendants charged with several federal substantive wire fraud offenses. ${ }^{111}$ On the "last day of evidence presentation," which occurred during "the morning of September 22[,] . . . a juror was hospitalized with symptoms consistent with COVID[-]19."112 When the defendants predictably alleged "juror coercion during deliberations owing to the COVID[-]19 pandemic," the district court denied their challenges, relying, in part, on an anonymous poll conducted after the infected juror was excused that indicated that eleven jurors wanted to

court to declare a mistrial because he failed to prove that the jury's deliberations were less accurate merely because they occurred during the COVID-19 pandemic).

106. Wilson, supra note 104, at 68-69.

107. See Brenda Vose, Francis T. Cullen, \& Heejin Lee, Targeted Release in the COVID-19 Correctional Crisis: Using the RNR Model to Save Lives, 45 AM. J. CRIM. Just. 769, 769 (2020) (providing examples of how the pandemic affected incarcerated individuals); see also, e.g., Wilson v. Williams, 961 F.3d 829, 847 (6th Cir. 2020) (Cole, $\mathrm{J}$. concurring in part and dissenting in part) (finding that the Federal Bureau of Prisons' failure to mitigate coronavirus-spread at the petitioners' prison "constitutes sufficient evidence for the district court to have found that petitioners were likely to succeed on their Eighth Amendment claim").

108. Commonwealth v. Delmonico, 251 A.3d 829, 840 (Pa. Super. Ct. 2021).

109. $I d$.

110. Id. at 839 (noting that "the jury selection process is crucial to the preservation of a criminal defendant's constitutional right to an impartial jury" because the Sixth and Fourteenth Amendment rights to an impartial jury and due process extend throughout the entirety of a criminal trial).

111. See United States v. Vorley, No. CR 00035, 2021 WL 1057903, at *1 (N.D. Ill. Mar. 18, 2021).

112. Id. at $* 2$. 
"proceed with the trial" and did not feel a need to "consult ... with a medical professional about potential COVID-19 exposure."113

Fluctuations in the pandemic's severity and rate of transmissionespecially with the unexpected onset of the Delta variant in the summer of 2021-have caused some courts to reconsider their decision to hold even socially-distanced jury trials. ${ }^{114}$ Eventually, even in the criminal setting, courts will need to consider the possibility that jury trials need to be modernized and brought online.

\section{Bringing Jury Trials into the 21st Century}

One of the more encouraging lessons of COVID-19 was just how rapidly institutions, including the judiciary, can change when pushed to do so. But changes need not be merely reactive. Instead, they can inspire a more profound rethinking of the jury as an institution.

In this Part, we outline six ways to reinvent jury trials. These reforms include using many more jurors to secure representativeness rather than using peremptory challenges to undermine it; increasing the use of video presentations to untether time and place of trial; condensing and reorganizing trial presentation; changing the time and place of where jurors serve; creating a nationwide jury pool for national civil cases while expanding the pool in criminal cases; and aggregating juror votes individually rather than having jurors deliberate secretly together. As we describe our proposed reforms, we take care to mention constitutional and legal barriers, which are addressed more directly in the next Part. If adopted, these reforms will increase juries' accuracy, efficiency, and democratic legitimacy, thereby furthering the jury's institutional functions.

\section{A. Larger Juries, Without Peremptory Challenges}

Aristotle is credited with first articulating the notion of "the wisdom of the crowd," which stands for the proposition that many minds are better than one mind. ${ }^{115}$ In 1785, French polymath Marquis de Condorcet published his famous Jury Theorem, which explained that, if a hypothetical juror's rate of accuracy on a question is at least $50 \%$,

113. $I d$.

114. See, e.g., Nannette Jolivette Brown, COVID-19: General Order 21-11, U.S. Dist. Cт. FOR E. Dist. LA. 1 (Aug. 18, 2021), https://www.laed.uscourts.gov/sites/default/files/pdfs/EDLA-General\%20Order\%2021-11\%20Sus-

pending\%20Jury\%20Trials.pdf [https://perma.cc/84ZJ-WMY6]; Dina Arévalo, Delta Variant Prompts Renewed Federal Court Restrictions, MYRGVNews (Aug. 7, 2021), https://myrgv.com/featured/2021/08/07/delta-variant-prompts-renewed-federal-courtrestrictions/ [https://perma.cc/5ERF-WC96] ("The current surge of COVID-19 cases and Delta variant infections has increased the risks to public health and those involved in selecting juries and conducting jury trials," reads the order signed by U.S. District Judges Ricardo H. Hinojosa, Randy Crane and Micaela Alvarez.").

115. Aristotle, Politics 223, 225 (H. Rackham trans., Harv. Univ. Press 1990); see generally JAmes Surowiecki, The Wisdom of Crowds 3-22 (2005). 
then every additional juror voting on the question will increase accuracy. ${ }^{116}$

In 1906, Sir Francis Galton-a (rather elitist) British statisticianwitnessed a contest at a country fair in Massachusetts. ${ }^{117}$ A showman asked those attending the fair to estimate the weight of an ox for prize money. ${ }^{118}$ The animal's actual weight was 1,198 pounds. ${ }^{119}$ Remarkably, the median guess of 1,207 pounds was accurate within one percent of the true value. (The average was 1,197 pounds. ${ }^{120}$ ) After replicating the results, Galton was forced to conclude that collective estimates are generally more accurate than individual ones. ${ }^{121}$ This contributed to the insight that a group's individual assessments can be modeled as a probability distribution of responses with the median often appearing near the true value of the quantity to be estimated. ${ }^{122}$

But the number of individual estimates matters greatly. Had Galton instead randomly chosen only six to twelve of the crowd members' guesses, the median value would have been much less likely to approximate the true value. In that case, the serendipity of chance would have determined the outcome.

As we think about jury trials, this risk of randomness is disconcerting. ${ }^{123}$ Jury trials aim at accuracy, conceived as the uncovering of a given case's (specific) facts followed by the application of the community's standards to those facts. ${ }^{124}$ In this sense, jury decisions are not

116. Marie Jean Antoine Nicolas de Caritat, Marquis de Condorcet, $E s$ say on the Application of Mathematics to the Theory of Decision-Making, in ConDoRCet: Selected Writings 33, 48-49 (Keith Michael Baker, ed., 1976). For a useful overview, see William P. Bottom, Krishna Ladha \& Gary J. Miller, Propagation of Individual Bias Through Group Judgment: Error in the Treatment of Asymmetrically Informative Signals, 25 J. Risk \& UnCERTAINTY 147, 152-54 (2002).

117. See Francis Galton, Vox Populi, 75 Nature 450, 450-51 (1907).

118. Id. at 450.

119. Id.

120. $I d$.

121. Id. at 451.

122. See Ulrik W. Nash, The Curious Anomaly of Skewed Judgment Distributions and Systemic Error in the Wisdom of Crowds, 9 PLOs ONE 1, 4 (2014), https://journals.plos.org/plosone/article?id=10.1371/journal.pone.0112386 [https://perma.cc/ RA42-8WFE] (discussing skewed distributions).

123. See Bruce Hay \& David Rosenberg, "Sweetheart" and "Blackmail" Settlements in Class Actions: Reality and Remedy, 75 Notre Dame L. Rev. 1377, 1404 (2000) ("[S]uppose that the odds are fifty percent that a given jury will return a verdict for the defendant and fifty percent that it will return a verdict for the class; and suppose that if the verdict is for the class, the expected damages will be $\$ 200$ million. . . . In such a setting, a single class trial is a highly risky proposition for both sides.").

124. See Christopher Tarver Robertson, Blind Expertise, 85 N.Y.U. L. REv. 174, 181 (2010) ("Both the procedure and substance of the American legal system are predicated on the assumption that, in any given case, there really is a fact of the matter. The elaborate procedures and evidentiary rules are designed 'to the end that the truth may be ascertained and proceedings justly determined.'") (quoting FED. R. EviD. 102)); see also Tehan v. United States, 382 U.S. 406, 416 (1966) ("The basic purpose of a trial is the determination of truth . . .."). 
unlike thermometers, bathroom scales, or other value-measuring instruments. ${ }^{125}$

If everyone who saw a case would rule identically, then a jury of twelve, six, or even one person would be quite sufficient. However, jury verdicts are infected by two types of potential measurement errors that arise from heterogeneity in the ways that individual jurors see cases. Some variations in a population are appropriate and need to be represented in a jury sample if its median vote is to represent the median perspective of the population. The effects of other variations-like an individual juror having an incorrect memory of what happened at trial, which can be conceived as an outlier-should be minimized. Consider how an appropriately sized jury addresses each goal.

Scholars have noted that "as an institution deeply woven into the fabric of popular governance, the American jury is a central site for political representation: the political representation of citizens by citizens." ${ }^{126}$ For that function to be accomplished, the jury's membership reflects the community from which it is drawn. ${ }^{127}$ Yet America is a famously diverse society with variations across racial, cultural, religious, economic, experiential, educational, ideological, and other dimensions. As the Supreme Court has said, the very notion of the jury recognizes such heterogeneity; the jury is supposed to capture a fair "cross-section of the community." 128

As an example of how this goal of representativeness can go awry, suppose that the actual population of potential jurors in a given locality is $18 \%$ Black, and suppose further that race is important to a case in that jurisdiction. ${ }^{129}$ By sheer (bad) luck of the draw, with only six to

125. See Michael J. Saks \& Peter David Blanck, Justice Improved: The Unrecognized Benefits of Aggregation and Sampling in the Trial of Mass Torts, 44 Stan. L. REV. 815, 847 (1992) ("Think of the jury as a measuring instrument, like a thermometer or a bathroom scale."); Hillel J. Bavli, Sampling and Reliability in Class Action Litigation, 2016 Cardozo L. Rev. De Novo 207, 210-11 (2016) ("[I]f a single claim is tried ten times independently (each trial with a new selection of trier of fact, attorneys, etc.), it is likely that there would be ten distinct verdicts. But, if there is a single correct outcome associated with the claim, then judgment variability reflects errordisparities between the observed outcomes and the 'correct' outcome." (emphasis in original)).

126. Ethan J. Leib, Michael Serota \& David L. Ponet, Fiduciary Principles and the Jury, 55 WM. \& MARY L. REv. 1109, 1147 (2014) (emphasis in original). But see Fleming v. Chi. Transit Auth., 397 Fed. App'x 249, 249 (7th Cir. 2010) ("[T]he Supreme Court has not recognized a Constitutional mandate that jury pools in civil cases reflect a fair cross-section of the community.").

127. See Robert M. Lawless, Jennifer K. Robbennolt \& Thomas S. Ulen, Empirical Methods in LaW 117, 122 (2d. ed. 2016) (discussing sampling bias).

128. Thiel v. S. Pac. Co., 328 U.S. 217, 220 (1946) (citing Smith v. Texas, 311 U.S. $128,130(1940))$.

129. See generally Portia Pedro, A Prelude to a Critical Race Theoretical Account of Civil Procedure, 107 VA. L. Rev. OnLINe 143, 143 (2021) ("shar[ing] a personal experience with police as part of suggesting that Black people's interactions with police might be a source of collective identity and might help us (Black proceduralists, liti- 
twelve jurors, it would be quite possible to end up with a final panel that is entirely white. The problem of fair representation is even worse if one considers the importance of intersectionality. ${ }^{130}$

In the 1940s, the Supreme Court said that it "would be impossible" to have a jury that "contain[s] representatives of all the economic, social, religious, racial, political[,] and geographical groups of the community." ${ }^{131}$ Yet, the way to get a representative jury is to increase the size of the sample, so that it includes a critical mass of each group. ${ }^{132}$

The second source of measurement error involves jurors making human mistakes whether from bad memory, inattention, incomprehension, distraction, or prejudice. ${ }^{133}$ One can conceive such errors as outliers, in an otherwise well-working process of discernment.

Voir dire has long been one traditional solution to this concern that a juror may be biased and unable to impartially resolve the facts of the case. ${ }^{134}$ By questioning jurors and then excluding some, either for cause or peremptorily, attorneys and judges are empowered to weed out bias. ${ }^{135}$ However, the evidence suggests that jury challenges just do not work. If, as is commonly done, challenges are based on jurors' own statements that they can or cannot be fair, research shows that prospective jurors are incapable of accurately assessing biases or reporting them to the court. ${ }^{136}$ If challenges are based on the hunches of trial attorneys, research shows that they cannot reliably identify which jurors will likely be adverse. ${ }^{137}$

gators, and scholars of color) to see some of the role of racial subordination within policing and procedure.").

130. See generally, Kimberle Crenshaw, Mapping the Margins: Intersectionality, Identity Politics, and Violence Against Women of Color, 43 Stan. L. Rev. 1241, 1244 (1991) ("us[ing] the concept of intersectionality to denote the various ways in which race and gender interact").

131. Thiel, 328 U.S. at 220.

132. See generally Michael J. Saks \& Mollie Weighner Marti, A Meta-Analysis of the Effects of Jury Size, 21 L. Hum. BeHAv. 451, 451 (1997).

133. See, e.g., Matthew Blackwell, James Honaker \& Gary King, A Unified Approach to Measurement Error and Missing Data: Overview and Applications, 46 Soc. Methods \& Rsch. 303, 304 (2015).

134. Rosales-Lopez v. United States, 451 U.S. 182, 188 (1981) ("Voir dire plays a critical function in assuring the . . right to an impartial jury will be honored."); see also Pointer v. United States, 151 U.S. 396, 408-09 (1894) (affirming the importance of the opportunity to inspect jurors "for the due administration of justice"); Valerie P. Hans, Challenges to Achieving Fairness in Civil Jury Selection, Pound Civ. Just. Inst. 14, https://papers.ssrn.com/sol3/papers.cfm?abstract_id=3899957\&dgcid=EJournal_ htmlemail_litigation:procedure:ejournal_abstractlink (Aug. 11, 2021) [https:// perma.cc/V9A8-RDGD].

135. See Rosales-Lopez, 451 U.S. at 188.

136. See David V. Yokum, Christopher Robertson \& Matt Palmer, The Inability to Self-Diagnose Bias, 96 Denver L. Rev. 869, 869 (2019).

137. See Dennis J. Devine, Jury Decision Making 46-48 (2012) (describing the "pessimistic" findings of empirical research on attorney juror-picking). 
Even worse, the United States Supreme Court has recognized that voir dire habitually reduces the petit jury's representativeness. ${ }^{138} \mathrm{Su}$ perficially, it may seem that giving both sides of a case the power to challenge jurors counterbalances any problem, but that is incorrect because the background distribution of traits in the jury pool is often imbalanced. As Jeffrey Abramson explains, "the side targeting a minority religion or race or ethnic group for removal from the jury always has an advantage over the side furtively seeking to purge members of the majority." 139 In a 2018 article, titled The Jim Crow Jury, Thomas Ward Frampton recently "demonstrate[d] that the systematic exclusion of nonwhite jurors remains ubiquitous." 140

Although lawyers are not supposed to use race or gender in their peremptory challenges, ${ }^{141}$ they need only give "a plausible reason, even [if] an irrational one" as justification for any particular decision to exclude a juror. ${ }^{142}$ Accordingly, even if luck produced a representative group of jurors on the basis of race or gender, it is not hard for litigants to secure a jury consisting of $100 \%$ of their preferred race or gender to decide the case. ${ }^{143}$ And, of course, race and gender are only two protected classes; attorneys can and do use all sorts of other pernicious bases-e.g., religion or class-to strike jurors, further undermining the jury's representative function. ${ }^{144}$

Some scholars have argued for the abolition of the peremptory challenge, recognizing that it has no constitutional mandate (except perhaps for criminal defendants). ${ }^{145}$ Other common law countries

138. See, e.g., Holland v. Illinois, 493 U.S. 474, 485 (1990) ("[M]any groups are regularly excluded from the petit jury through peremptory challenge.").

139. Jeffrey Abramson, Two Ideals of Jury Deliberation, 1998 U. ChI. Legal F. 125, 133 (1998).

140. Thomas Ward Frampton, The Jim Crow Jury, 71 Vand. L. Rev. 1593, 1598 (2018).

141. Batson v. Kentucky, 476 U.S. 79, 99 (1986); J.E.B. v. Alabama, 511 U.S. 127, 145-46 (1994) (extending the Batson rule to gender).

142. Arthur L. Burnett, Sr., Abolish Peremptory Challenges: Reform Juries to Promote Impartiality, CRIM. Just. MAG., Fall 2005, at 26, 28 ("[I]f . . . the prosecutor offers any plausible reason, even an irrational one, the trial judge can reject the challenge to the peremptory strike."); see also Robin Charlow, Tolerating Deception and Discrimination After Batson, 50 Stan. L. Rev. 9, 10-11 (1997); Jonathan Abel, Batson's Appellate Appeal and Trial Tribulations, 118 Colum. L. Rev. 713, 715 (2018).

143. See, e.g., Woodward v. Epps, 580 F.3d 318, 336 (5th Cir. 2009) (denying Batson relief, even where "every black person was removed from the jury panel, and the jury that was eventually empaneled was composed entirely of white members"); Mitcham v. Davis, 103 F. Supp. 3d 1091, 1096 (N.D. Cal. 2015) ("The prosecutor used his peremptory challenges to strike every African American called to the jury box.").

144. See, e.g., Minnesota v. Davis, 504 N.W.2d 767, 771 (Minn. 1993) (refusing to extend Batson to peremptory challenges where the objection to the strike was based on a person's religion or religious affiliation).

145. See, e.g., Abbe Smith, A Call to Abolish Peremptory Challenges by Prosecutors, 27 Geo. J. Legal Ethics 1163, 1164 (2014); LaCrisha L.A. McAllister, Comment, Closing the Loophole: A Critical Analysis of the Peremptory Challenge and Why It Should Be Abolished, 48 S.U. L. REv. (forthcoming 2021) (manuscript at 2-3); see also Ilya Somin, Derek Chauvin Jury Selection Process Highlights Need to Stop Dumb- 
have rejected the tool. ${ }^{146}$ Although they emerged from England, the country ultimately abandoned peremptory challenges, finding that they were irrational historical relics ill-suited to an ideally representative institution like the jury. ${ }^{147}$

In the United States, significantly, Arizona became the first state to decide against allowing peremptory strikes in both civil and criminal jury trials; the ban becomes effective in 2022. ${ }^{148}$ Aware of the social science suggesting that eliminating peremptories "would help juries be more reflective of the community and help eliminate discrimination or unconscious bias," Arizona's Supreme Court changed the law. ${ }^{149}$

Given modern social science, the practice of challenging individual jurors is obviously anachronistic. Imagine if a professional polling company like Gallup, attempting to discern a population's opinion on some issue such as mask wearing, instructed pollsters to toss out a certain number of respondents on nothing more than an intuition that they may be biased. Likewise, the voir dire process tries in advance to identify and remove potential jurors who the judge or a lawyer supposes is likely to render an inaccurate verdict.

A second approach operates ex post, when a trial judge or appellate court supposes that a given jury's decision is contrary to its own assessment of the "great weight of the evidence." Under both the civil and criminal rules of procedure, judges have a remarkable power to throw out jury decisions-almost as if they were a thirteenth juror with veto power. ${ }^{150}$ Since this power exists precisely for situations

ing Down Juries, Volokh Conspiracy (Mar. 18, 2021, 2:38 PM), https://reason.com/ volokh/2021/03/18/derek-chauvin-jury-selection-process-highlights-need-to-stopdumbing-down-juries/ [https://perma.cc/7X5U-SZLR] (highlighting how one criterion used to dismiss jurors - knowledge about the case-may yield less informed, less impartial juries to the extent that jurors who lack knowledge of high-profile events are systematically excluded).

146. See Eugene Tate, Ernest Hawrish \& Stanley Clark, Communication Variables in Jury Selection, 24 J. Commc'N 130, 131, 134 (1974) (describing the vastly different approaches in Canada and Britain, especially in civil cases).

147. See Samuel J. Cohen, The Regulation of Peremptory Challenges in the United States and England, 6 B.U. INT'L L.J. 287, 313-14 (1988) (noting that parliament's primary rationale in doing away with peremptories was to preserve the random, or representative, nature of jury selection).

148. Brenna Goth, Arizona Bans Use of Peremptory Strikes in State Jury Trials, Bloomberg L. (Aug. 30, 2021, 6:01 PM), https://news.bloomberglaw.com/us-lawweek/arizona-bans-use-of-peremptory-strikes-in-state-jury-trials [https://perma.cc/ 6REV-5PFC].

149. $I d$.

150. FED. R. Civ. P. 59(a)(1)(A) ("The court may, on motion, grant a new trial on all or some of the issues ... after a jury trial, for any reason for which a new trial has heretofore been granted in an action at law in federal court . . .."); see Cassandra Burke Robertson, Judging Jury Verdicts, 83 Tul. L. Rev. 157, 161-62 (2008) (discussing the procedure for new trial in both civil and criminal cases and noting that it is more common for state courts to "review the weight of the evidence"); see, e.g., Norton v. Norfolk S. Ry. Co., 567 S.E.2d 851, 854 (S.C. 2002) ("South Carolina's thirteenth juror doctrine is so named because it entitles the trial judge to sit, in essence, as 
where the judge cannot identify any particular error that was made during the jury trial or deliberations, Cassandra Burke Robertson has aptly called this the doctrine of "invisible error." 151 It is arguably a corrosive power, one which undermines the very purposes of having jurors in the first place. ${ }^{152}$

Imagine a Gallup pollster throwing out results that do not cohere with her own view, claiming that some "invisible error" in the first sample's results necessitates convening a second sample. Such an approach defeats the very purpose of the poll.

Rather than using such hunches to try to eliminate erroneous decisions ex ante (through voir dire) or ex post (through new trial motions), a more scientific approach to polling public perceptions is to simply recruit a sample large enough to outvote the outliers, rendering them sheer noise, distracting from the central tendency. ${ }^{153}$

Using modern tools of power analysis and confidence intervals (or margins of error), scientists can estimate the range of values that cannot be reasonably rejected from the alternative hypothesis. ${ }^{154}$ All of the values that fall within the confidence interval can be considered consistent with the observed data. Values that fall outside the confidence interval can be rejected. Larger sample sizes yield more precise estimates because each additional observation reduces the chance that the outcome is due to lucky (or unlucky) draws from a given population.

The ideal confidence level turns on our tolerance for error. ${ }^{155}$ If it matters little how a case turns out, we might tolerate being right just $75 \%$ of the time. But if we want our legal system to send accurate deterrence signals to primary actors, and if we wish to use the state's coercive power to redistribute resources only when necessary, we might demand a much greater degree of accuracy—say, 99\%. Scien-

the thirteenth juror when he finds 'the evidence does not justify the verdict,' and then to grant a new trial based solely "upon the facts."' (citation omitted)).

151. Cassandra Burke Robertson, Invisible Error, 50 Conn. L. Rev. 161, 164 (2018).

152. See U.S. Const. amend. VII ("[N]o fact tried by a jury, shall be otherwise reexamined in any Court of the United States, than according to the rules of the common law."). But see William V. Dorsaneo, III, Reexamining the Right to Trial by Jury, 54 SMU L. REv. 1695, 1719 (2001) ("The power of trial judges to grant new trials because verdicts or particular jury findings are contrary to the clear weight of the evidence is universally recognized and supported by ample common law precedent." (citing 3 W. Blackstone, Commentaries *387)).

153. See generally Daniel Kahneman, Olivier Sibony \& Cass R. Sunstein, Noise: A Flaw in Human Judgment vii (2021).

154. Carmen R. Wilson VanVoorhis \& Betsy L. Morgan, Understanding Power and Rules of Thumb for Determining Sample Sizes, 3 Tutorials Quantitative MethODS FOR Psych. 43, 44-46 (2007). Note that we could have this discussion alternatively in terms of $p$-values or even Bayesian analysis, but confidence intervals help illustrate the dynamics at different sample sizes.

155. Richard A. Posner, An Economic Approach to the Law of Evidence, 51 STAN. L. Rev. 1477, 1511 (1999) ("There is no magic to the [5\%] criterion . . .."). 
tists routinely use $95 \%$ as the confidence level, which means they tolerate being wrong in roughly one in twenty cases. ${ }^{156}$ As an example, we use that same threshold here, presuming that our legal system should aim for at least this level of accuracy when rendering decisions that collectively affect millions of lives and trillions of dollars.

Figure 1 illustrates the application of $95 \%$ confidence intervals to a binary outcome (i.e., a verdict), with six or twelve jurors in the first columns. With a hypothetical two-thirds of sampled jurors agreeing that the plaintiff should recover, the confidence interval still overlaps $50 \%$, meaning that we cannot reject the null hypothesis (i.e., that most jurors in the population would favor the other side). In the given case, at scientific levels of confidence, we cannot say that most potential jurors would agree with the actual jurors assembled to hear the case. The outcome may be due to sheer chance.

Figure 1

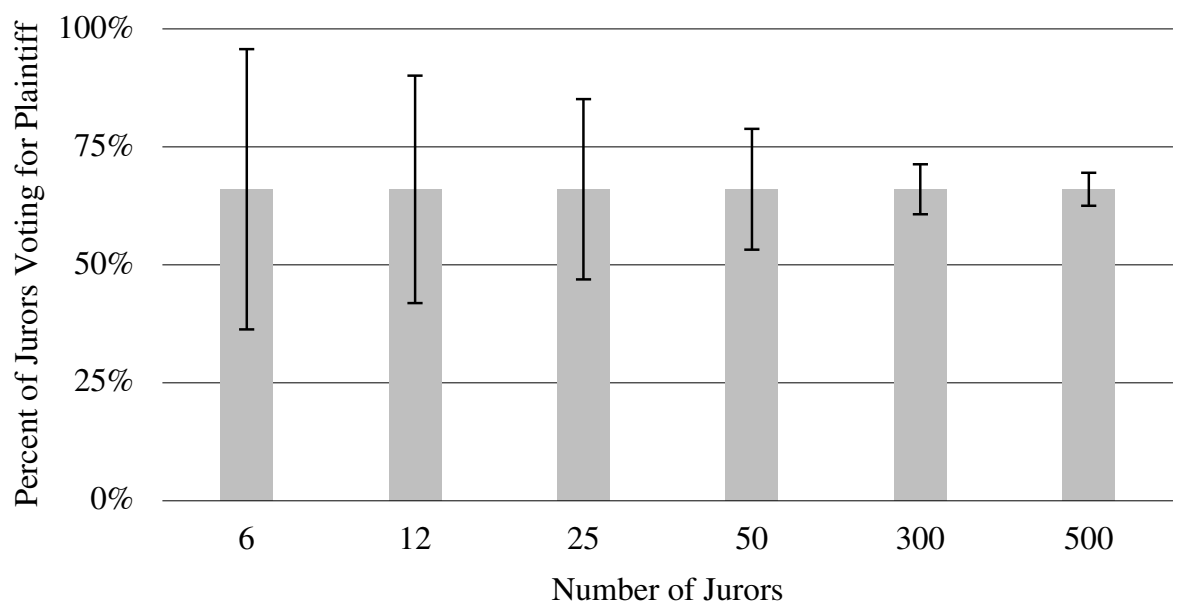

The columns in Figure 1 show the possible effects of alternative jury sizes. More than doubling the sample to twenty-five jurors does not raise the lower bound of the confidence interval above $50 \%$. But with a fifty-juror sample - if two-thirds still vote for the plaintiff-our confidence interval narrows such that we can predict that most others in the community will cast a similar vote. With a reasonable degree of scientific certainty, we can then eliminate the possibility that our observed verdict for the plaintiff results from chance.

Courts could dynamically assign jury sizes to reach greater efficiencies. Larger juries are more important where the stakes are particularly high because the costs of error are higher. It is obviously worse, from a social and individual perspective, to erroneously redistribute $\$ 250$ million than $\$ 25,000$. 
Larger juries are also especially advantageous in close cases. If only $55 \%$ of jurors ultimately believe a defendant is liable, then a much larger jury will be required to reject the null hypothesis than if $99 \%$ of jurors believe a defendant is liable. In the latter case, a relatively small jury will be sufficient to reject the alternative hypothesis (that most jurors in the population would instead vote against liability). It is for this reason that social scientists often undertake pilot studies to inform the optimal sample size for their pivotal study. ${ }^{157}$ Such tests can be undertaken for civil trials-or sufficiently experienced judges can gauge how close a case may be before assigning an appropriately scaled jury.

Unless courts dynamically assign jury sizes, they would need a onesize-fits-all rule. It seems unlikely that six to twelve jurors are the optimal number, especially if we can reduce the costs of summonsing more jurors (as our other reforms suggest). Fifty jurors might be reasonable. However, if we desire sufficient precision on not only the binary liability outcomes but also the specific amount of awarded damages, even larger juries will be necessary, perhaps numbering in the hundreds or thousands per case. Jurors are, after all, notorious for sometimes-wide-ranging damage assessments especially regarding non-economic damages. ${ }^{158}$ In one realistic experiment, for instance, the average juror award for pain and suffering was \$2.9 million, but the standard deviation was nearly $\$ 4.3$ million. ${ }^{159}$ Statistical mechanisms can be used to aggregate responses and compress variability, but larger numbers of jurors are nonetheless necessary to generate scientifically reasonable damage estimates. ${ }^{160}$

Research suggests that jury service brings incidental benefits to jurors and society. Those who have served as jurors are more likely to vote and report improved civic engagement. ${ }^{161}$ Larger juries could increase these benefits. Of course, to the extent that jury service is burdensome, expanding juries might increase this societal burden.

157. E.g., Edwin R. van Teijlingen \& Vanora Hundley, The Importance of Pilot Studies, Sociology At SurRey 1-4 (2001), https://sru.soc.surrey.ac.uk/SRU35.PDF [https://perma.cc/T2C7-4YRN].

158. Valerie F. Reyna et al., The Gist of Juries: Testing a Model of Damage Award Decision Making, 21 Psych. Pub. PoL'y \& L. 280, 280 (2015).

159. See Shari Seidman Diamond et al., Juror Judgments About Liability and Damages: Sources of Variability and Ways to Increase Consistency, 48 DePaul L. ReV. 301, 315-16 (1998).

160. See John Campbell, Bernard Chao, Christopher Robertson \& David V. Yokum, Countering the Plaintiff's Anchor: Jury Simulations to Evaluate Damages Arguments, 101 Iowa L. REV. 543, 567 (2016).

161. John Gastil et al., Jury Service and Electoral Participation: A Test of the Participation Hypothesis, 70 J. Pol. 351, 351, 359 (2008); see also Valerie P. Hans, John Gastil \& Traci Feller, Deliberative Democracy and the American Civil Jury, 11 J. EMPIRICAl LEgal STUd. 697, 697 (2014) (While a "seven-state study of jury service and voting records found no overall boost in civic engagement following service on civil juries, ... . jurors who served on criminal cases did show increased civic engagement following their jury service."). 
Considered alone, the prospect of larger juries raises several logistical questions. Where would fifty or more jurors sit? Who would pay the additional costs? How could they possibly deliberate? These problems dissolve if some or all our complementary reforms are adopted.

\section{B. Asynchronous Video Presentation}

A jury trial is not unlike a play. By analogy, the courthouse is the theater, the attorneys and witnesses the actors, the judge the director, and the jurors the audience. When the common law jury was conceived by the Founders' British predecessors, such live, face-to-face entertainment was the norm. (The telegraph was not invented until $1844,{ }^{162}$ the telephone until $1876,{ }^{163}$ and the television until $1927 .{ }^{164}$ )

Although the raw technologies have now existed for decades, it was not until the advent of online video-streaming in the 2000s, followed by its widespread diffusion in the 2010s, that it became practically and economically feasible to record and edit trials for juries to watch and decide individual cases. Now, attorneys can record and edit high-definition video using the phones in their pockets or the computers at their desks. At higher levels of professionalism, involving dedicated cameras, videographers, and editors, it is now possible to produce quality videos at relatively low costs.

Suppose that, instead of producing live trials, courts created highquality videos capturing all aspects of a trial, including opening arguments, testimonial and documentary evidence, closing arguments, and the judge's instructions. Even before the COVID-19 pandemic, we had several proofs of concept. In extant civil litigation, it has long been routine to video-record depositions in all but the smallest cases. ${ }^{165}$ When a witness cannot attend a live trial, or when a party seeks to use prior testimony to impeach a witness, these videos are often edited and played at trial. Similarly, jury researchers often use video stimuli to represent the trial process. ${ }^{166}$ As early as 1994, one scholar argued that the notion of the "video trial" was gaining support. ${ }^{167}$ And-as Part II makes clear-the coronavirus pandemic has drawn great interest toward trial by videoconference.

162. Morse Code \& the Telegraph, HistORy.cOM, https://www.history.com/topics/ inventions/telegraph (June 6, 2019) [https://perma.cc/XWD4-ZQX8].

163. Who Is Credited with Inventing the Telephone?, LiBr. Cong. (Nov. 19, 2019), https://www.loc.gov/everyday-mysteries/item/who-is-credited-with-inventing-the-telephone/ [https://perma.cc/75GH-CR6N].

164. Sarah Pruitt, Who Invented Television?, History.COM (June 29, 2021), https:// www.history.com/news/who-invented-television [https://perma.cc/YQA9-TGAL].

165. Perritt, supra note 55, at 1071.

166. Christopher T. Robertson \& David V. Yokum, The Effect of Blinded Experts on Juror Verdicts, 9 J. EMPIRICAL Legal StUd. 765, 765 (2012) (reviewing this literature).

167. Perritt, supra note 55, at 1071-72. 
Video trials yield several potential advantages. First, video-editing allows evidentiary presentation to be more condensed and, therefore, focused. The current debate on whether and how courts should limit trial time evinces perceptions that modern trials largely waste the time of everyone involved. ${ }^{168}$ Indeed, raw testimony involves plenty of proverbial throat-clearing, parrying, dodging, and repeating. In contrast, the use of video depositions in today's trials shows how they can be condensed from raw material consuming, say, seven hours (or more) to just an hour or so, featuring only the key testimony that each party designates as most essential. ${ }^{169}$ This distillation obviously offers increased efficiency. Concision may also improve accuracy by improving juror attention and comprehension. Eliminating extraneous testimony lessens the risk that jurors will grow bored, confused, or distracted.

Second, an edited video trial allows the court to resolve objections to improper evidence or arguments in advance. In major cases, judges often use pre-trial Daubert hearings to similarly proscribe what experts may and may not say. ${ }^{170}$ For many other issues, however, parties must object during trial once a purportedly objectionable piece of evidence is offered, often in front of the jury but ideally at sidebar. This process wastes more jury time and risks contaminating the jury by exposing it to improper evidence. In contrast, in video trials, objections can be resolved in advance, and if sustained, improper material can be edited out. These procedures are already used for parties to designate and register objections to video depositions in standard trials. The technique could be expanded to cover a complete video trial.

Decades of social science research suggest it is ineffective or even counterproductive to tell jurors to ignore material they have already but erroneously seen. ${ }^{171}$ The primary advantage of these approaches is to vindicate and reinforce the Rules of Evidence; a properly edited video virtually eliminates the risk that a jury will be exposed to inappropriate material that might contribute to an erroneous decision. Even "live" online trials could include a five-or-so second delay-not

168. See Stephen D. Susman \& Richard L. Jolly, An Empirical Study on Jury Trial Innovations, Civ. Jury Project 101, 103 (Feb. 2017), https://civiljuryproject.law. nyu.edu/wp-content/uploads/2016/10/sds-rlj_Empircal-Study-on-Trial-Innovations.pdf [https://perma.cc/R73Y-E59M] (arguing for time limits on trials).

169. See Fed. R. Civ. P. 30(d)(1) (Generally, "a deposition is limited to one day of [seven] hours."); see also Estate of Spear v. Comm'r, 41 F.3d 103, 116 (3d Cir. 1994) ("Although live testimony is generally preferable to videotaped testimony, the absence of such testimony, even from a key witness, is only minimally prejudicial when that witness is adverse and when there is a videotaped deposition that can be introduced in lieu of live testimony.").

170. See, e.g., Carlson v. Bioremedi Therapeutic Sys., Inc., 822 F.3d 194, 201 (5th Cir. 2016) (reversing and remanding after "the district court disregarded its gatekeeping function to determine the admissibility of evidence outside of the presence of the jury").

171. See Nancy Steblay et al., The Impact on Juror Verdicts of Judicial Instruction to Disregard Inadmissible Evidence: A Meta-Analysis, 30 L. \& Hum. BeHAv. 469, 477 (2006) https://doi.org/10.1007/s10979-006-9039-7. 
unlike delays already used in live television broadcasting ${ }^{172}$ - to enable court staff to omit objections.

Third, a video trial would allow jurors to simply rewind a video to refresh their memories when deciding cases. During deliberations, today's courts sometimes provide trial transcripts or excerpts thereof, but these lack key markers of witness credibility (e.g., physical demeanor), which is a primary consideration for jurors. ${ }^{173}$ Indeed, courts regularly discourage juries from an overreliance on transcripts: "The transcript is not authoritative. If you remember something different from what appears in the transcripts, your collective recollection is controlling." 174 A huge body of research suggests that human memory is far from perfect and-arguably-now obsolete since technologies like video recording are now widely available. ${ }^{175}$

Fourth, video-taped materials can be reused within the judicial system. Appellate courts often complain that they cannot evaluate aspects of a witness's demeanor at trial. This inability to view the actual trial is often cited as a primary reason why trial courts are "given much deference." 176 Rather than poring through "cold" transcripts, ${ }^{177}$ courts of appeals can simply watch videos, thereby seeing the same thing as the trial judge.

There may be other reasons for general deference to lower courts, but reversals will nonetheless be necessary at times. Video trials can dramatically reduce the costs of remanding to correct an error. For example, suppose that an appellate court determines that the trial judge erred in excluding certain testimony. The testimony can simply be reinserted and the case played out before another set of jurors rather than remanding the case and having the court conduct another

172. E.g., Matt Carey, ABC to Impose Delay on Oscar Telecast, CNN (Feb. 5, 2004, 9:13 AM), http://us.cnn.com/2004/SHOWBIZ/Movies/02/05/sprj.aa04.abc.oscar.delay/ [https://perma.cc/9KQ5-32JG].

173. See California v. Green, 399 U.S. 149, 198 (1970) (Brennan, J., dissenting) ("No such determination of credibility is possible when the witness comes before the trial factfinder by the reading of a cold transcript."); see also Tennant v. Peoria \& P. U. Ry. Co., 321 U.S. 29, 35 (1944) ("It is the jury, not the court, which is the factfinding body. It weighs the contradictory evidence and inferences, judges the credibility of witnesses, receives expert instructions, and draws the ultimate conclusion as to the facts.").

174. United States v. Montgomery, 150 F.3d 983, 999-1000 (9th Cir. 1998) (quoting instructions the district court provided for the jury).

175. See generally Daniel L. Schacter \& Elizabeth F. Loftus, Memory and Law: What Can Cognitive Neuroscience Contribute?, 16 Nature Neuroscience 119, 119 (2013).

176. Snyder v. Louisiana, 552 U.S. 472,479 (2008) (citation omitted).

177. See Rice v. Collins, 546 U.S. 333, 343 (2006) ("Appellate judges cannot on the basis of a cold record easily second-guess a trial judge's decision ...."); United States v. Shinderman, 515 F.3d 5, 17 (1st Cir. 2008) ("Only rarely-and in extraordinarily compelling circumstances-will we, from the vista of a cold appellate record, reverse a district court's on-the-spot judgment concerning the relative weighing of probative value and unfair effect." (quoting Freeman v. Package Mach. Co., 865 F.2d 1331, 1340 (1st Cir. 1988)). 
jury trial, which might consume years of time and millions of dollars. ${ }^{178}$ Saving time would be especially important in actual-innocence cases involving wrongful imprisonment.

Or suppose that the case is part of a mass tort, involving hundreds or thousands of similarly situated plaintiffs. Notwithstanding the common issues (e.g., defendant conduct) each plaintiff may need to prove specific facts (e.g., whether they relied on the misrepresentation, or whether a certain chemical caused their injuries). Accordingly, the main body of the case can be optimized in the video trial for reuse in every subsequent case with a different module inserted for evidence specific to each plaintiff. This procedure would be much more efficient than conducting a live trial for each plaintiff.

One limitation of asynchronous video trials is that jurors will be unable to inject their own questions into trial-an important innovation of trial practice. ${ }^{179}$ The court, or litigants themselves, may instead generate and resolve such questions from mock jurors before finalizing the trial video, thereby ensuring that the most common questions get answered. This limitation would not, of course, apply in live, online trials where video is merely offered to jurors after trial and during deliberation. Indeed, in live trials, jurors' abilities to submit questions may be enhanced, because they will be able to non-intrusively type and submit their questions while watching the trial in a private manner that might well cause them to hesitate less than during an in-person trial. Relatedly, submitting questions to a court technician over the Internet may be less intimidating for jurors. ${ }^{180}$

Another potential limitation involves the risk of improper editing such that the videos the jurors see are not actually representative of the evidence. This concern has already been surmounted in the use of video depositions at trial, and it could easily be surmounted in videotaped trials as well: The trial judge would give both parties a chance to preview the materials and to submit objections about material that was improperly included or excluded. Such trial decisions will, of course, be subject to appellate review with the typical deferential standard for trial management and evidentiary decisions.

A final group of concerns are psychological. We have already mentioned one such consideration: that unwatched jurors are less responsible jurors. But there are several other considerations.

First, video trials may be less engaging than physical ones. The literature on online education is instructive. One recent review of the liter-

178. For an analogous approach, see D. Alex Winkelman et al., An Empirical Method for Harmless Error, 46 ARIz. ST. L.J. 1405, 1405 (2014) (testing variations on the same trial to determine whether an error was harmless).

179. See Susman \& Jolly, supra note 168 , at 110-11.

180. See Michael Shammas, Thoughts on Optimizing Time \& Attention in Virtual Trials, Civ. Jury Project (July 9, 2020), https://civiljuryproject.law.nyu.edu/the-trialof-counting-trials-2/ [https://perma.cc/DRU9-TEVK]. 
ature concludes that "[t]aken as a whole, there is robust evidence to suggest [that] online learning is generally at least as effective as the traditional format." 181 Thus, for the cognitive purpose of imparting understanding, it seems that video is no impediment. ${ }^{182}$ The past year has provided further evidence that online teaching environments can be generally effective if properly produced.

Video trials could be optimized to use best practices from the educational context. For example, educators have found that "spaced" learning is ideal. ${ }^{183}$ Courts could accordingly release segments of trial videos in a pre-planned, timed manner to optimize focus and attention. Some research suggests that the ideal attention span is about twenty-five minutes, with five-minute breaks interspersed throughout to give the brain time to consolidate information. ${ }^{184}$ Even if courts are unlikely to make live online sessions that short, judges should consider using frequent breaks to avoid "Zoom fatigue" during synchronous hearings and trials. ${ }^{185}$

Second, video testimony may be less emotionally arousing than physical testimony. (Picture jurors sitting feet away from a sobbing plaintiff.) Summarizing the literature, Susan Bandes and Jessica Salerno write that "there is some evidence that videotaped testimony

181. Tuan Nguyen, The Effectiveness of Online Learning: Beyond No Significant Difference and Future Horizons, 11 MERLOT J. OnLIne LeARning \& Teaching 309, 309 (2015).

182. Another commonsense safeguard when crucial monologues like jury instructions are delivered virtually_aside from making them especially concise and clearinvolves making trial video available so that daydreaming jurors can fill in gaps in their knowledge. It may also be advisable to send each juror a transcript of important monologues like jury instructions.

183. Cf. Praveen Shrestha, Ebbinghaus Forgetting Curve, Psychestudy (Nov. 17, 2017), https://www.psychestudy.com/cognitive/memory/ebbinghaus-forgetting-curve [https://perma.cc/C2XJ-55PQ] (The "Ebbinghaus forgetting curve describes the decrease in ability of the brain to retain memory over time."); see also Harvey Singh, What Is Spaced Learning \& (Why Does It Matter) in eLearning?, InstanCy (Jan. 13, 2021), https://www.instancy.com/blog/what-is-spaced-learning/ [https://perma.cc/ MF4B-9WHN] ("Ebbinghaus hypothesized the Forgetting Curve and introduced the spacing effect." So with the spaced-learning "approach of teaching, learners can retain the information taught in [a] course.").

184. Alan Henry, Productivity 101: An Introduction to the Pomodoro Technique, LIFEHACKER (July 12, 2019, 4:31 PM), https://ifehacker.com/productivity-101-a-primer-to-the-pomodoro-technique-1598992730 [https://perma.cc/NJ5Y-Z5C7]; see generally Adam Gazzaley \& Larry D. Rosen, The Distracted Mind: Ancient Brains in a High-Tech World xiii-xvi (2016); see also Loren Dunn, The Pomodoro-Technique and 3 More Research-Backed Study Tips, Forbes (Apr. 26, 2016, 11:01 AM), https://www.forbes.com/sites/noodleeducation/2016/04/26/thepomodoro-technique-and-3-more-research-backed-study-tips/?sh=6257eeb85027

[https://perma.cc/2CK3-ELBJ] ("Check out the Pomodoro Technique, just one of many tools that can help to combat procrastination, in this case by breaking study sessions into manageable pieces.").

185. Liz Fosslien \& Mollie West Duffy, How to Combat Zoom Fatigue, Harv. Bus. Rev. (Apr. 29, 2020), https://hbr.org/2020/04/how-to-combat-zoom-fatigue [https:// perma.cc/8PDQ-P6XN]. 
evokes less empathy than in-court testimony, though video also presents opportunities for close-ups and other artistry that might ameliorate the effect of the decision maker's lack of proximity to the witness."186

Yet videos can be quite emotionally arousing. After all, the potential for such arousal is the exact rationale that judges use today when excluding certain video presentations (for example, victim-impact statements and day-in-the-life videos) that may be too emotionally arousing. ${ }^{187}$ Even if video does mute emotional arousal, it is unclear whether this counts as a disadvantage. ${ }^{188}$ The Supreme Court has said that " $[\mathrm{t}]$ he jury system is premised on the idea that rationality and careful regard for the court's instructions will confine and exclude jurors' raw emotions." ${ }^{189}$ Indeed, as Federal Rule of Evidence 403's distinction between the probative and the prejudicial reflects, emotion is a hallmark of unfair prejudice. ${ }^{190}$ Video, especially carefully edited video, may facilitate an appropriate degree of dispassionate consideration of evidence.

\section{Shorter, Edited Trials}

The 2021 Academy Award winner for best picture, Nomadland, is 12 minutes shy of two hours. ${ }^{191}$ The 2020 Academy Award winner for best picture, Parasite, is 132 minutes. ${ }^{192}$ The 2019 Academy Award winner, Green Book, is 130 minutes. ${ }^{193}$ The 2018 winner, The Shape of Water, is 123 minutes. ${ }^{194}$ The success of these award-winning films suggests that a rich, comprehensive story can be told in a matter of hours.

186. Susan A. Bandes \& Jessica M. Salerno, Emotion, Proof and Prejudice: The Cognitive Science of Gruesome Photos and Victim Impact Statements, 46 ArIz. ST. L.J. 1003, 1040 (2014) (internal citation omitted); see also Susan A. Bandes \& Neal Feigenson, Empathy and Remote Legal Proceedings, 51 Sw. L. REv. (forthcoming Dec. 2021).

187. Bandes \& Salerno, supra note 187 at $1040-41$.

188. See generally Dan Simon, In Praise of Pedantic Eclecticism: Pitfalls and Opportunities in the Psychology of Judging, in The Psychology of Judicial Decision MAKING 131-48 (David Klein \& Gregory Mitchell eds., 2010).

189. CSX Transp., Inc. v. Hensley, 556 U.S. 838, 841 (2009).

190. Bandes \& Salerno, supra note 186, at 1006 (first quoting Lisa Kern Griffin, Narrative, Truth and Trial, 101 GEO. L.J. 281, 314 n.181 (2012); then quoting Victor J. Gold, Federal Rule of Evidence 403: Observations on the Nature of Unfairly Prejudicial Evidence, 58 WASH. L. REv. 497, 503 (1983)).

191. Nomadland, IMDB, https://www.imdb.com/title/tt9770150/ [https://perma.cc/ 8MNN-VMR7].

192. Parasite, IMDB, https://www.imdb.com/title/tt6751668/ [https://perma.cc/ 5D6K-VD58].

193. Green Book, IMDв, https://www.imdb.com/title/tt6966692/ [https://perma.cc/ X8DS-XFCN].

194. The Shape of Water, IMDB, https://www.imdb.com/title/tt5580390/ [https:/ perma.cc/K7J7-4WSZ]. 
We have already suggested that one benefit of asynchronous video trials is that, by eliminating extraneous material, they facilitate somewhat shorter trials than live trials. This benefit might yield trials that are on average $20 \%$ or even $40 \%$ shorter than current trials. But it is worth considering whether the length and format of trials should be even more profoundly changed.

Currently, trials-both criminal and civil-consist of each side giving an opening statement before calling witnesses, displaying documentary and physical evidence, and delivering a closing argument. Under this time-honored format, key evidence is typically shared three times (through opening statements, testimonial and documentary evidence, and closing statements), and key jury instructions are given at least twice (first by both attorneys and then by the judge). The repetition is worthwhile if the trial is going to stretch into days and weeks but may well be unnecessary in a shorter presentation. Instead, what if an entire two-week trial were condensed into, say, a 130minute video, including evidentiary highlights from each side (e.g., video clips of testimony), and incorporating succinct yet clear jury instructions?

Litigators already give condensed closing arguments that integrate the court's legal instructions and highlight key evidence often in an hour or less. Whether juror accuracy is enhanced by watching the entire trial in addition to the closing arguments-which already concisely summarize the relevant evidence and the proper legal standard-is an open empirical question. Closing arguments alone may be sufficient.

Scholars have long advocated for (and courts have recently experimented with) instructing jurors on the elements of the legal cause of action earlier during the trial itself. ${ }^{195}$ This reform would help jurors make legal sense of the factual evidence they hear. Courts are also experimenting with letting litigants introduce witnesses to explain their testimony's relevance to the case. A closing argument inherently accomplishes both functions.

Research on decision-making suggests that people typically do not withhold judgment until the very end of the process of receiving information. ${ }^{196}$ They instead make an early assessment and-with the receipt of additional information-selectively assimilate that

195. E.g., Nancy S. Marder, Bringing Jury Instructions into the Twenty-First Century, 81 Notre Dame L. Rev. 449, 451 (2006); Neil P. Cohen, The Timing of Jury Instructions, 67 TENN. L. REV. 681, 688 (2000).

196. See Reid Hastie, The Role of "Stories" in Civil Jury Judgments, 32 U. Mich. J.L. REFORM 227, 238 (1999) ("[J]urors' judgments are based on summaries of the evidence structed as chronological narratives."); see also Robert J. MacCoun, Experimental Research on Jury Decision-Making, RAND 1 (1989), https://www.rand.org/content/dam/rand/pubs/reports/2007/R3832.pdf [https://perma.cc/JMJ3-ZXBS] ("[D]espite judges' instructions to the contrary, many jurors form tentative verdict preferences early in the trial[.]"). 
information to accord with their initial judgment. ${ }^{197}$ This process makes it unlikely that adding a 131st minute, a 141st minute, or even several hundred more minutes of trial time could change the average juror's decision for the better. Each additional minute yields diminishing marginal utility. At some point, more minutes-even ones featuring completely novel, useful information-exert negative effects, including fatigue, distraction, boredom, or irritability.

Of course, complex cases involving more parties or technical evidence will continue to require longer trials. ${ }^{198}$ Videos created for such complex cases may optimally feature running times more akin to epics-Gandhi (191 minutes) ${ }^{199}$ or Gone with the Wind (226 minutes) ${ }^{200}$ - than action films. Nonetheless, our experience advising parties to complex cases and observing oral advocacy at the appellate and trial levels suggests that most litigants can make a coherent case within an hour or so.

Aside from efficiency and accuracy, due process requires sufficient time for litigants to tell their own stories and get a fair hearing. ${ }^{201}$ Nonetheless, courts have for decades exercised their powers to place reasonable limits on trial time. ${ }^{202}$ The question is not whether to limit the video trial time, but rather, how much condensation is appropriate if justice is to be done in any one case.

\section{Breaking Time \& Place Limitations}

If the foregoing reforms are implemented such that radically shortened trials are conducted by video, the geography of trials can be rethought. Presently, to stage live, physical trials, the lawyers, judge, witnesses, jurors, and court staff are all forced to be in the exact same place at the exact same time. Witnesses must travel from the opposite side of the world if they can even be subpoenaed to appear at all. ${ }^{203} \mathrm{In}$ major cases, each side may bring dozens of personnel (including law-

197. See MacCoun, supra note 196, at 2-3.

198. Nora Freeman Engstrom, The Diminished Trial, 86 Fordham L. Rev. 2131, 2134 (2018) (reviewing evidence that trials have become shorter in recent years but that a few protracted trials are still conducted every year).

199. Gandhi, IMDB, https://www.imdb.com/title/tt0083987/ [https://perma.cc/ QG7S-RRV6].

200. Gone with the Wind, IMDв, https://www.imdb.com/title/tt0031381/ [https:// perma.cc/WDE3-7K2Z].

201. Compare John E. Rumel, The Hourglass and Due Process: The Propriety of the Time Limits on Civil Trials, 26 U.S.F. L. Rev. 237, 238 (1992) ("Trial judges must consider ... due process rights and interests when establishing time limits ...."), with Nora Freeman Engstrom, The Trouble with Trial Time Limits, 106 GEO. L.J. 933, 933 (2018) ("[A] limit can, theoretically, be so strict and arbitrary that its imposition constitutes a violation of due process ....").

202. Fed. R. Civ. P. 16(c)(2)(O) (allowing the court to "establish[] a reasonable limit on the time allowed to present evidence").

203. See FED. R. Civ. P. 45(c)(1)(A)-(B) (allowing witnesses to be subpoenaed if nearby). 
yers, presentation consultants, paralegals, and support staff) to a trial site in a remote federal courthouse (e.g., the Eastern District of Texas, Sherman Division) and live there for a month or longer. The practical difficulty of aligning all those schedules against professional and personal obligations, as well as exigent circumstances like health or weather emergencies, often causes trials to be cancelled or rescheduled to a later date (i.e., "continued").

Video potentially enhances efficiency-in terms of both travel costs and opportunity costs-reducing the delays that accompany continuances. The attorneys, witnesses, and judge may perform their functions at convenient times and places (for them) while the jurors can also perform their duties at another convenient time and place.

Physically convening jurors entails substantial monetary and opportunity costs. Jurors will often prefer to serve at home or the office or a nearby library. Such a change may be less expensive in direct costs (e.g., a bus fare or parking), indirect costs (e.g., childcare), and opportunity costs (e.g., lost wages) than traveling to a courthouse. And they would often prefer to schedule their service at a convenient time, which may well be different than that imagined by the judge or other parties. Perhaps after dinner or during a slow morning at work?

Currently, thousands of potential jurors are excused for hardship, sometimes after suffering the difficulty of having to appear at court to plead with the judge. ${ }^{204}$ Many others serve despite some level of hardship that is nonetheless insufficient for excusal. ${ }^{205}$ By reducing the barriers to service, this change could secure a more representative jury willing and able to serve.

Not long ago, Americans conducted all manner of routine tasks downtown, from voting to renewing a driver's license. Such tasks are increasingly completed remotely. Most states now offer online vehicle registration that is making trips to the DMV a thing of the past. ${ }^{206} \mathrm{As}$ of early 2021, five states conduct elections solely by mail; thirty-four

204. See Joanna Sobol, Hardship Excuses and Occupational Exemptions: The Impairment of the Fair Cross-Section of the Community, 69 S. CAL. L. Rev. 155, 159 (1995) ("A significant number of citizens avoid jury service by means of a system of excuses an occupational exemptions that defers to claims of 'hardship."”); see also Hiroshi Fukarai \& Edgar W. Butler, Organization, Labor Force, and Jury Representation: Economic Excuses and Jury Participation, 32 Jurimetrics J.L. SCI. \& TeCH. 49, 51 (1991) ("[T]he disproportionate jury representation caused by excuses for economic hardship undermines the legitimacy of the jury system and of jury verdicts in the eyes of citizens.").

205. Thiel v. S. Pac. Co., 328 U.S. 217, 223-24 (1946) (holding that "[a] juror shall not be excused by a court for slight or trivial causes, or for hardship, or for inconvenience to said juror's business, but only when material injury or destruction to said juror's property or of property entrusted to said juror is threatened" (citation omitted)); $c f . i d$. ("[A] federal judge would be justified in excusing a daily wage earner for whom jury service would entail an undue financial hardship.").

206. See Vehicle Registration Laws by State, FindLaw, https://www.findlaw.com/ traffic/drivers-license-vehicle-info/state-vehicle-registration-information.html (June 20, 2016) [https://perma.cc/62BE-M59Z]. 
states and the District of Columbia permit qualified voters to cast mail-in ballots. ${ }^{207}$

As noted above, the COVID-19 pandemic caused some courts to adapt. For example, the Yolo County Superior Court permitted "potential jurors to respond to summons by Zoom or phone," while also promulgating "easy step-by-step instructions" featuring "hyperlinked-and quite large-buttons" for jurors to click to submit their reply to summons. ${ }^{208}$ Courts that move to online trials or hearings might also benefit from "creating a technological 'Jury Service Staff' available to answer questions by phone or email."209

With high-speed Internet, customized video can now be reliably delivered at little cost. Citizens can watch proceedings via a variety of devices including laptops, tablets, smartphones, and smart-home devices. A basic 7" tablet with video-streaming capability can be purchased for $\$ 40$ - less than one day's minimum wage. ${ }^{210}$ Nearly $60 \%$ of Americans now pay for video-streaming services like Netflix. ${ }^{211}$

Admittedly, a digital divide persists. Indigent and rural Americans disproportionately lack access to high-speed Internet and networkready devices. ${ }^{212}$ But these problems are not insurmountable. For example, such citizens could travel to their nearest public library or courthouse. Alternatively, there may be ways to mail them loaner devices with cellular-data capabilities.

When jurors serve from home in online trials, it may be difficult to monitor whether they are having ex parte conversations or consulting extraneous materials. On the other hand, using larger sample sizes in concert with shorter trials might make other sorts of misconduct more difficult. For instance, our reforms make it largely infeasible for litigants to find-much less contact-jurors whose service may be limited to an hour or two. Similarly, serving from home or the office creates a risk that jurors will be interrupted by the mailman, a co-

207. Voting Outside the Polling Place: Absentee, All-Mail, and Other Voting at Home Options, Nat'L Conf. St. Legislators (Sept. 24, 2020), http://www.ncsl.org/ research/elections-and-campaigns/absentee-and-early-voting.aspx [https://perma.cc/ 8V64-ZYSJ].

208. Online Jury Trials Are Possible, supra note 58.

209. Id.

210. E.g., Vankyo MatrixPad Z1 7” Tablet, The STORE, https://thestore.com/p/refurbished-vankyo-matrixpad-z1-7-tablet-android-81-oreo-go-32gb-emmcr-ips-hd-display-wi-fi-bluetooth-black-ts686494611399r?roistat=Merchant3_g

80086369672_online\%3Aen\%3AUS\%3A87723\&roistat_referrer,roistat_pos,gclid= EAIaIQobChMIpeei0LDz8QIVtW1vBB3vlQN_EAQYASABEgKoqPD_BwE [https://perma.cc/LQH4-8ZC8].

211. Steve Liesman, Nearly $60 \%$ of Americans Are Streaming and Most with Netflix: CNBC Survey, CNBC, https://www.cnbc.com/2018/03/29/nearly-60-percent-ofamericans-are-streaming-and-most-with-netflix-cnbc-survey.html (Mar. 29, 2018, 1:26 PM) [https://perma.cc/63FN-WRXE].

212. See A. Scheerder, Alexander van Deursen \& Jan van Dijk, Determinants of Internet Skills, Uses and Outcomes. A Systematic Review of the Second-and ThirdLevel Digital Divide, 34 Telematics \& Informatics 1607, 1608 (2017). 
worker, a pet, or any number of other things. Of course, for short interruptions, they can simply pause their video and resume when ready. Although interruptions are usually bad, due to spaced learning, intentional interruptions could actually benefit overall accuracy. ${ }^{213}$

Courts could ship jurors low-cost tablets, formatted both to prevent other tasks from being performed concurrently on the devices and to enable court personnel to monitor jurors' actions. ${ }^{214}$ Going further, the use of virtual-reality goggles will become increasingly feasible. ${ }^{215}$ The devices can detect when users remove them, and the virtual-reality experience is substantially more engaging than video. ${ }^{216} \mathrm{~A}$ virtualreality headset also moots concerns that jurors might engage in distracting behavior during trial and deliberation while lessening the risk of a juror impermissibly recording the trial. (This is because (1) unlike with a traditional screen, it is nearly impossible to use a phone or portable camera to record what is playing on a virtual-reality headset; and (2) courts could prophylactically disable the recording functions on virtual-reality devices.)

Our time-and-place reform can also be applied dynamically, much like jury sequestration is currently applied on a case-by-case basis. For most routine cases, it may be harmless and efficient for jurors to serve at locations of their choosing. In the wake of COVID-19, Yolo County took care to include in its guidelines "that every hearing or proceeding that can be done virtually is done virtually, including jury orientation and hardship hearings." 217

A more general concern relates to the seriousness and solemnity of the trial. ${ }^{218}$ Unless jurors are required to be physically present in a courthouse to view video or other digital evidence, they could feel a lack of gravity that might undermine the accuracy of their decisions. As of now, the problem is largely speculative; research is needed on this question to both quantify the problem and test potential solutions,

213. Shrestha, supra note 183.

214. See supra Part III(D).

215. See Anjanette H. Raymond \& Scott J. Shackelford, Jury Glasses: Wearable Technology and Its Role in Crowdsourcing Justice, 17 CARdozo J. Conflict Resol. 115, 118 (2015) (arguing for reforms that "could reduce judicial backlogs, temper . . . attempts to avoid participation in dispute resolution, promote legal cognizance, and improve community participation, in addition to reducing the prevalence of personal bias in decision making"); see also Natalie Salmanowitz, Unconventional Methods for a Traditional Setting: The Use of Virtual Reality to Reduce Implicit Racial Bias in the Courtroom, 15 U.N.H. L. REv. 117, 117 (2016).

216. See Salmanowitz, supra note 215 , at 142-43 ("[I]mmersive virtual environments would likely generate stronger, longer-lasting effects due to their more vicarious and life-like nature.").

217. Online Jury Trials Are Possible, supra note 58.

218. Marder, supra note 55, at 264-65 ("The architecture of the courtroom, with actors in their designated places, the formality of the procedures, and the presence of the parties who will be affected by the jury's verdict, remind jurors of the seriousness of their task. An online mock juror lacks such a setting."). 
including virtual representation of the same factors, such as architecture, that support solemnity in the courtroom.

In exigent circumstances, like a pandemic, remote service could mitigate the risks and anxiety of physical proximity. ${ }^{219}$ More generally, this reform serves efficiency by reducing costs for jurors to serve. In doing so, the reform could also marginally enhance the jury's chief functions of accuracy and democratic engagement, if it improves the representativeness of the jurors able to serve.

\section{E. A National Jury Pool for National Civil Cases}

The foregoing section recommends breaking the geographic link between jurors and the courthouse, allowing jurors to serve from their public libraries, their offices, or even their homes. This reform begs another question: When, for a given case, the alleged wrongdoing has a national scope, why should the jury deciding the case be limited to one judicial district? Moving to remote video trials could enable national jury pools in cases of national importance, as some have suggested. ${ }^{220}$

To be sure, local juries are appropriate for local cases. Local trials reflect "the community's interest in local autonomy when it comes to judging crimes [or torts or contract breaches] committed on its soil."221 A local jury may well bring local community values, and perhaps some common sense about relevant local facts, like how busy a particular town's intersection may be, as it relates to a car accident there.

However, in cases where a party is a national or multinational corporation, and the relevant behaviors (like price fixing, patent litigation, or product safety) are also national, it is inappropriate for the case to be resolved by a jury located in one particular part of one particular state, which may have peculiar biases, values, or experiences that are nationally unrepresentative. Cases against corporations are often tried in their hometowns, which may be dominated by their own workers (and a broader local economy that depends on them), even though the corporate behavior affects consumers or stockholders

219. Wilson, supra note 104, at 68-69 (noting that juries deliberating during coronavirus may have felt rushed and been less representative due to differential levels of concern about COVID-19 felt by different ethnicities and partisans).

220. See Laura G. Dooley, National Juries for National Cases: Preserving Citizen Participation in Large-Scale Litigation, 83 N.Y.U. L. REv. 411, 411 (2008) (advocating for national pools to "eliminate incentives for parties to forum-shop [that] would make the decisionmaking body representative of the population that will feel the effects of its decision"); see also Luke McCloud \& David Rosenberg, A Solution to the Choice of Law Problem of Differing State Laws in Class Actions: Average Law, 79 Geo. Wash. L. Rev. 374, 374 (2011) (suggesting a similar solution for choice of law issues in class action litigation); Abbe R. Gluck \& Elizabeth Chamblee Burch, $M D L$ Revolution, 96 N.Y.U. L. REv. 1, 11, 72 (2021) (noting the impact that jury trials might have on the development of multidistrict litigation).

221. Abramson, supra note 139, at 152. 
nationwide. Such an imbalance in jury representativeness could skew their view of the facts.

Indeed, scholars, courts, and litigants have expressed concern that "sympathetic [local] jury pools" are unrepresentative and that the current system creates incentives for litigants to "forum shop" for favorable jurisdictions. ${ }^{222}$ Even when outside their hometowns, major companies have sought to exploit their repeat-player status by funding extravagant charitable works like ice-skating rinks for the enjoyment of the local population (i.e., the jury pool). ${ }^{223}$

In other cases, the problem is flipped: A local jury is hostile to a litigant. ${ }^{224}$ Take the case of Jeffrey Skilling, former CEO of Enron, the Houston company that collapsed after a spectacular case of securities fraud. ${ }^{225}$ As it crumbled, many Houstonians with Enron-tied retirement accounts lost their entire life savings, and several potential jurors reported personally knowing people injured by Enron's fraud. ${ }^{26} \mathrm{Re}-$ latedly, some scholars have argued that when "the local population [has] a vested interest in the outcome of the case, ... [a] presumption of bias should extend to the entire community." 227 Yet the Supreme Court ultimately affirmed Skilling's conviction. ${ }^{228}$ Its decision relied on little more than the jurors' reassurances, rendered under pressure from the trial judge, that they could be "fair and impartial." 229

Given the findings of modern psychology, such potentially biased local trials seem medieval and-with modern communications technology-completely unnecessary. ${ }^{230}$ For federal criminal cases, the Sixth Amendment's Vicinage Clause requires that juries be drawn from the state or federal district where the crime was committed, ${ }^{231}$

222. Alisha Kay Taylor, Comment, What Does Forum Shopping in the Eastern District of Texas Mean for Patent Reform?, 6 J. Marshall Rev. Intell. Prop. L. 570, 583 (2007); see also Andrei Iancu \& Jay Chung, Real Reasons the Eastern District of Texas Draws Patent Cases-Beyond Lore and Anecdote, 14 SMU ScI. \& Tech. L. REv. 299, 301-02 ("One of the oft-cited reasons for the District's popularity, as well as its undeserved reputation, has been the allegedly 'plaintiff-friendly juries' who are 'predisposed to find for plaintiffs and award large damages."' (internal citations omitted)).

223. Anthony Zurcher, Why a Small Town in Texas Had Samsung's Ear, BBC News (May 27, 2017), https://www.bbc.com/news/world-us-canada-40021491 [https:// perma.cc/G223-694X].

224. See Victor E. Schwartz, Sherman Joyce \& Cary Silverman, West Virginia as a Judicial Hellhole: Why Businesses Fear Litigating in State Courts, 111 W. VA. L. REv. 757, 758 (2009).

225. Skilling v. United States, 561 U.S. 358, 367-68 (2010).

226. $I d$.

227. Jordan Gross, If Skilling Can't Get a Change of Venue, Who Can? Salvaging Common Law Implied Bias Principles from the Wreckage of the Constitutional Pretrial Publicity Standard, 85 Temp. L. Rev. 575, 620 (2013).

228. Skilling, 561 U.S. at 367-68.

229. Id.

230. See Yokum et al., supra note 136, at 871-72 (detailing the failure of selfdiagnosis).

231. U.S. Const. amend. VI. 
and we acknowledge that using national jury pools for criminal cases may be more difficult than in civil cases. In our analysis in Part IV below, we argue that for such cases, however, federal criminal juries should at the very least become district or state-wide because the Federal Rules of Criminal Procedure narrow vicinage much more than the Sixth Amendment requires. ${ }^{232}$

\section{F. Vote-Aggregation Without Deliberation}

The book and movie 12 Angry Men popularized the notion that through passionate argumentation and obdurate insistence, a minority of jurors, or even one heroic holdout, can save a jury from an unjust verdict. ${ }^{233}$ The jury deliberation has been romantically described as "collecting people together into a conversation fed by difference but fueled by a search for common ground." 234

The reality is quite different. As Harry Kalven, Jr., and Hans Zeisel argued, based on their collected data from actual juries and trial judges, deliberation "might well be likened to what the developer does for an exposed film; it brings out the picture, but the outcome is predetermined." 235 Indeed, far from empowering holdouts as in 12 Angry Men, the typical function of jury deliberation is to (eventually) enable the majority to outvote the minority, just as Condorcet recommends. ${ }^{236}$ In more recent work, Shari Diamond and Jonathan Casper conclude that "the median [individual juror award pre-deliberation] is the best single predictor of the jury's final verdict." ${ }^{237}$ Consistent with Kalven and Zeisel's findings from the 1960s, this more recent work suggests that jury deliberations do little more than consume timehours, days, and sometimes weeks-while delaying an inevitable outcome that could have been gleaned by a simple mathematical aggregation of each juror's individual vote. ${ }^{238}$ For this reason, leading jury scholars typically take the median vote of mock jurors as predictive of trial outcomes. ${ }^{239}$

232. See infra Part IV.

233. Jason D. Reichelt, Standing Alone: Conformity, Coercion, and the Protection of the Holdout Juror, 40 U. Mich. J. L. ReFORM 569, 570 (2007).

234. Abramson, supra note 139, at 160.

235. MacCoun, supra note 196, at 2-3 (citation omitted).

236. CONDORCET, supra note 116.

237. Shari Seidman Diamond \& Jonathan D. Casper, Blindfolding the Jury to Verdict Consequences: Damages, Experts, and the Civil Jury, 26 L. \& SoC'y Rev. 513, 546 (1992); see also S. Femi Sonaike, The Influence of Jury Deliberation on Juror Perception of Trial, Credibility, and Damage Awards, 1978 BYU L. Rev. 889, 902 (1978) (finding that the median was better than the mean).

238. Diamond \& Casper, supra note 237, at 559.

239. E.g., Neil Vidmar, Medical Malpractice and the American Jury 197 (1995); see also Campbell et al., supra note 160, at 557. But see David Schkade, Cass R. Sunstein \& Daniel Kahneman, Deliberating About Dollars: The Severity Shift, 100 Colum. L. Rev. 1139, 1152-53 (2000) (finding higher punitive damages awards compared to the median of individual votes); Daniel Kahneman, David Schkade \& Cass 
But it is not just a function of jurors being outvoted; they are often ground down by social pressure. In a classic 1950s experiment, Solomon Ash demonstrated a "conformity" effect. ${ }^{240}$ A group of participants were tasked with publicly estimating which of three lines matched the length of a separate line. ${ }^{241}$ The task was repeated several times. ${ }^{242}$ Unbeknownst to one person-the actual subject-all the other participants were hired staff, or "confederates." ${ }^{43}$ These confederates publicly gave their answers - which were clearly incorrectbefore the research participant was asked to answer. ${ }^{244}$ On average, three of four participants eventually began parroting the confederates. $^{245}$ This classic work has been successfully replicated and extended. ${ }^{246}$ More recent work suggests that social pressure is a bigger cause of people changing opinions than the exchange of information. ${ }^{247}$

Even when there is diversity of initial viewpoints, people usually focus on points of agreement-a tendency known as shared-information bias. ${ }^{248}$ Discussion, in turn, highlights agreed-upon positions, which reinforces confidence in those beliefs. ${ }^{249}$ Occasionally, the group's final collective position becomes substantially more extreme than that of any single individual. ${ }^{250}$

Notwithstanding this evidence, the classic story is that vigorous jury deliberation enhances jury accuracy and mitigates biases. There exists a rich social-science literature on group deliberation, which is only gestured at here. ${ }^{251}$ Its implications are not promising. Said Sunstein:

R. Sunstein, Shared Outrage and Erratic Awards: The Psychology of Punitive Damages, 16 J. Risk \& UnCERTAINTY 49, 72-75 (1998).

240. Solomon E. Asch, Studies of Independence and Conformity: I. A Minority of One Against a Unanimous Majority, 70 Psych. Monographs: Gen. \& Applied 1, 3 (1956).

241. Id.

242. Id.

243. Id.

244. Id.

245. Id. at 21.

246. E.g., Kazuo Mori \& Miho Arai, No Need to Fake It: Reproduction of the Asch Experiment Without Confederates, 45 InT'L J. Psych. 390, 390 (2010).

247. E.g., Daniel J. Mallinson \& Peter K. Hatemi, The Effects of Information and Social Conformity on Opinion Change, Plos ONE 1 (May 2, 2018), https://journals.plos.org/plosone/article?id=10.1371/journal.pone.0196600 [https://perma.cc/ Z7VG-BNGJ].

248. Gwen M. Wittenbaum, The Bias Toward Discussing Shared Information: Why Are High-Status Group Members Immune?, 27 CoмmC'N Rsch. 379, 393 (2000) (highlighting how decision-making groups "fail to disseminate effectively their unshared information").

249. See Cass R. Sunstein, The Law of Group Polarization, 10 J. Pol. PhiL. 175, 179 (2002).

250. Id. at 176.

251. See, e.g., Michael X. Delli Carpini, Fay Lomax Cook \& Lawrence R. Jacobs, Public Deliberation, Discursive Participation, and Citizen Engagement: A Review of the Empirical Literature, 7 AnN. Rev. Pol. ScI. 315, 324 (2004) ("Like other forms of participation, engagement in political talk-especially the more 'costly' forms, such as 
If individual jurors are biased because of pretrial publicity that misleadingly implicates the defendant, or even because of the defendant's unappealing physical appearance, juries are likely to amplify rather than correct those biases. Groups have been found to . . . be more affected by the biasing effect of spurious arguments from lawyers; to be more susceptible to the "sunk cost fallacy"; and to be more subject to choice-rank preference reversals. ${ }^{252}$

Simply putting people together for a discussion is, thus, no panacea for cognitive failures.

To be fair, some research does find that deliberation is useful. For example, Jessica Salerno and Michael McCauley exposed fifty-five undergraduate mock-trial participants to testimony given by both low and high-quality experts. ${ }^{253}$ They found that the individual mock jurors were more discerning of quality after rather than before deliberating. ${ }^{254}$

In theory, deliberation could enhance factfinding by allowing fellow jurors to fill in gaps in colleagues' memories. ${ }^{255}$ But we have already suggested that reliance on sheer memory should become obsolete especially if we implement much shorter trial presentations and utilize rewindable video presentations. Moreover, even if deliberation could fill in gaps in jurors' memories, scholars have unfortunately found that the jurors who verbally dominate deliberations do not necessarily have the most accurate memories. ${ }^{256}$ In fact, those who change their recollections are not typically the least accurate ones but the least confident ones. As W.B. Yeats once wrote, "[t]he best lack all conviction[,] while the worst are full of passionate intensity." 257 This finding parallels the famous Dunning-Kruger effect, which generally proposes that confidence and knowledge are inversely correlated. ${ }^{258}$

deliberative meetings-appears to be linked to socioeconomic status and education ...."); Mathew D. McCubbins \& Daniel B. Rodriguez, When Does Deliberating Improve Decisionmaking?, 15 J. ConTeMP. Legal Issues 9, 12 (2006) (presenting experiments with "results which indicate that deliberation, even when attempted under ideal conditions, does not improve social welfare, and, in all but rare circumstances, may decrease it").

252. Cass R. Sunstein, Deliberating Groups Versus Prediction Markets (or Hayek's Challenge to Habermas), 3 EPISTEME 192, 198 (2006) (internal citations omitted).

253. Jessica M. Salerno \& Michelle R. McCauley, Mock Jurors'Judgments About Opposing Scientific Experts: Do Cross-Examination, Deliberation and Need for Cognition Matter?, 27 Ам. J. Forensic Psych. 37, 37 (2009).

254. Id.

255. Mary E. Pritchard \& Janice M. Keenan, Does Jury Deliberation Really Improve Jurors' Memories?, 16 Applied Cognitive Psch. 589, 589 (2002).

256. Id. at 591.

257. Scott Simon, Opinion: Reading William Butler Yeats 100 Years Later, NPR (Nov. 28, 2020, 8:00 AM), https://www.npr.org/2020/11/28/939561949/opinion-readingwilliam-butler-yeats-100-years-later [https://perma.cc/2TQ5-RSUM].

258. See Gordon Pennycook et al., Dunning-Kruger Effects in Reasoning: Theoretical Implications of the Failure to Recognize Incompetence, 24 PyschonOMIC Bull. \& REv. 1774, 1774 (2017) ("The Dunning-Kruger effect refers to the observation that the incompetent are often ill-suited to recognize their incompetence."). 
As for why those with more accurate views tend not to lead deliberations, Lynn M. Sanders observes that "[w]hen Americans assemble in juries, they do not leave behind the status, power, and privileges that they hold in the outside world." ${ }^{259}$ Thus, deliberation can squelch the viewpoints of women, minorities, and other disadvantaged groups. Indeed, white men with college degrees are disproportionately made forepersons ${ }^{260}$ and when women speak, their words are perceived differently than identical words articulated by men. ${ }^{261}$ The fact that such issues would not have bothered the Framers, who after all systematically excluded women and African Americans from jury service, is yet further evidence of the incongruity of using an unchanged institution from 1789 to resolve disputes in 2021.

An additional risk of deliberation involves the possibility that outspoken jurors will share personal anecdotes and purported expertise, which then infects the views of fellow jurors. For example, in research on mock jurors deliberating on a case involving lower-back pain, individual jurors habitually cited purported knowledge, either personal or through acquaintances, of ideal clinical practice. ${ }^{262}$ As Paul Kirgis argued, "Specialized knowledge poses the same risks to the truth-seeking objectives of trial whether it enters the decision-making process through expert testimony or through the back door of juror background knowledge." ${ }^{263}$ When it comes in the front door, we have evidentiary rules and procedures so that unreliable testimony can be excluded from the evidentiary record at trial or at least cross-examined. ${ }^{264}$ When it comes to the same sorts of comments in the jury room, we just cross our fingers.

Aside from introducing extraneous factual claims, fellow jurors may also use rhetoric, repetition, racism, and outright demagoguery that would not be permitted of a trial witness or attorney in closing argu-

259. Lynn M. Sanders, Against Deliberation, 25 Pol. Theory 347, 364 (1997).

260. Valerie P. Hans \& Neil Vidmar, Judging the Jury 101 (1986).

261. Jessica Salerno \& Liana C. Peter-Hagene, One Angry Woman: Anger Expression Increases Influence for Men, but Decreases Influence for Women, During Group Deliberation, 39 L. \& Hum. BeHAv. 581, 581 (2015).

262. Megan S. Wright, Christopher T. Robertson \& David V. Yokum, Mock Juror and Jury Assessment of Blinded Expert Witnesses, in Blinding as a Solution to Bias 195, 202-04 (Christopher T. Robertson \& Aaron S. Kesselheim, eds., 2016); see also Grotemeyer v. Hickman, 393 F.3d 871, 878 (9th Cir. 2004) (finding no reversible error existed where "the jury foreman, referring to her experience as a medical doctor, opined that [defendant's] mental disorders caused him to commit his crime").

263. Paul F. Kirgis, The Problem of the Expert Juror, 75 TemP. L. REv. 493, 496 (2002); see also Kristin A. Liska, Note, Experts in the Jury Room: When Personal Experience Is Extraneous Information, 69 STAN. L. REv. 911, 911 (2017) ("By virtue of their own personal expertise, [expert jurors] pose a distinct risk of bringing in the sort of information other jurors are prohibited from seeking out by simply using personal experience to analyze the evidence and theories at trial.").

264. See FED. R. Evid. 606(a) ("A juror may not testify as a witness before the other jurors at the trial."); FED. R. EvID. 702(a) (requiring that expert witnesses be qualified by virtue of their "scientific, technical, or other specialized knowledge"). 
ments. ${ }^{265}$ It seems rather odd that the trial judge works so hard to ensure that jurors are not exposed to such inadmissible material during the actual trial, but-as between jurors after trial-anything goes! And per the procedural rules, the deliberations themselves are shrouded in secrecy, thus making it nearly impossible for litigants to challenge irrelevant, unreliable, and prejudicial interventions by jurors. ${ }^{266}$

Although one might counter that deliberation will cause jurors to mitigate biases and stereotypes, the literature is at best mixed. Deliberation may generally mitigate pre-existing stereotypes; however, if the stereotype is activated during trial, deliberating magnifies its effects. $^{267}$

We suggest that rather than deliberate as a group, jurors simply vote-a pragmatic solution, especially if juries become larger. After all, the function of attorneys' closing argument is to share divergent viewpoints and highlight salient evidence. With the benefit of this robust adversarial process, it is not clear how the jurors' own comments help fellow jurors make up their minds.

Of course, one might understandably worry that deliberation yields incidental benefits such as increasing a sense of political efficacy and democratic engagement. ${ }^{268}$ On the other hand, scholars have concluded that "real-life deliberation can fan emotions unproductively, can exacerbate rather than diminish power differentials ...., can make people feel frustrated with the system that made them deliberate, [can be] ill-suited to many issues, and can lead to worse decisions than would have occurred if no deliberation had taken place."269

265. See FED. R. Evid. 401, 403 (prohibiting irrelevant or unfairly prejudicial evidence); see also Zapata v. Vasquez, 788 F.3d 1106, 1110-11, 1124 (9th Cir. 2015) (granting relief after a prosecutor's inflammatory, ethnically charged comments).

266. See Tanner v. United States, 483 U.S. 107, 117 (1987) (applying a common law precursor to FED. R. EvID. 606, which prohibits inquiry into jury deliberations except in cases of "extraneous influence" from outside the jury itself, such as a bribe offered to a juror); Peña-Rodriguez v. Colorado, 137 S. Ct. 855, 859 (2017) (finding that the Sixth Amendment permits inquiry where a juror discloses statements exhibiting overt racial bias casting serious doubt on the fairness and impartiality of the jury's deliberations and resulting verdict). See generally Diane E. Courselle, Struggling with Deliberative Secrecy, Jury Independence, and Jury Reform, 57 S.C. L. REv. 203, 229 (2005) (discussing events that "allowed a peek into the jury deliberation room").

267. Tamara M. Haegerich, Jessica M. Salerno \& Bette L. Bottoms, Are the Effects of Juvenile Offender Stereotypes Maximized or Minimized by Jury Deliberation?, 19 Psych. Pub. Pol'y \& L. 81, 81 (2013) (discussing findings of mock jury studies).

268. See Michael E. Morrell, Deliberation, Democratic Decision-Making and Internal Political Efficacy, 27 Pol. BeHAv. 49, 49 (2005) ("[D]eliberation will not necessarily lead to direct, positive effects on citizens' internal political efficacy, but they also highlight the likelihood that face-to-face deliberation can lead citizens to feel more competent in their deliberative abilities.").

269. John R. Hibbing \& Elizabeth Theiss-Morse, Stealth Democracy: Americans' Beliefs About How Government Should Work 191 (2004). 
We have suggested that deliberation is often actually deleterious, even aside from the impracticality of having dozens or hundreds of jurors deliberating together, in connection with our proposal for dramatically larger juries. Nonetheless, there are other less profound reforms that could facilitate larger juries while preserving some forms of deliberation. For example, one potential alternative would involve using breakout groups or parallel juries wherein several groups of, perhaps, twelve jurors deliberate together, and then the juries' votes (rather than the jurors' votes) are aggregated to reach a verdict. ${ }^{270}$

Various methods of reduced-form deliberation are also possible. For example, each juror could submit comments, perhaps responding to various prompts, and those responses could then be circulated to all jurors or to a random selection of other jurors, who could then tag them or vote on them to promote or demote them, not unlike how some social-media platforms work. In this vein, recent scholarly work has shown how carefully constructed interventions can help crowds sort truth from falsehood. ${ }^{271}$

In short, even if deliberation were ideal, requiring that people be physically present while deliberating is not technologically necessary. And, from the social-scientific perspective of 2021, these secretive anything-goes conversations seem far from ideal.

\section{Constitutionality \& Legal Reforms}

This Part reviews the constitutionality and legality of our proposed reforms. Our assessment analyzes the Constitution's commitment to public trials, the Sixth and Seventh Amendments' jury-trial guarantees, and, for criminal cases, the Sixth Amendment's Confrontation Clause and Vicinage Clause. After concluding that our reforms are potentially constitutional, we analyze the permissibility of videoconferencing under the current Federal Rules of Criminal and Civil Procedure to examine the procedural innovations necessary to actualize the widescale use of online juries.

270. See Campbell et al., supra note 160, at 557 (using such a method for research purposes); see also Saks \& Blanck, supra note 125, at 819-26 (discussing Cimino v. Raymark Indus., 751 F. Supp. 649, 649 (E.D. Tex. 1990), which used two juries in a mass-tort context); Byron G. Stier, Jackpot Justice: Verdict Variability and the Mass Tort Class Action, 80 TEMP. L. REv. 1013, 1013 (2007) (arguing for the use of "multiple juries in individual cases").

271. E.g., Gordon Pennycook \& David G. Rand, Fighting Misinformation on Social Media Using Crowdsourced Judgments of News Source Quality, 116 Proc. NAT'L ACAD. SCIS. U.S. AM. 2521, 2521 (2019) ("[H]aving algorithms up-rank content from trusted media outlets may be a promising approach for fighting the spread of misinformation on social media."); Gordon Pennycook et al., Fighting COVID-19 Misinformation on Social Media: Experimental Evidence for a Scalable Accuracy-Nudge Intervention, 31 Psych. SCI. 770, 770 (2020) (suggesting that "nudging people to think about accuracy is a simple way to improve choices about what to share on social media"). 


\section{A. The Sixth and Seventh Amendments}

The Seventh Amendment guarantees the right to trial by jury for most civil cases. ${ }^{272}$ The substance of the Amendment has never been incorporated, but most states comply with the jury trial requirement anyway. ${ }^{273}$ Although not applicable to all cases and waivable by the parties, the right "is preserved to the parties inviolate." 274 Similarly, the Sixth Amendment contains the jury right along with the most fundamental rights that American criminal defendants enjoy. ${ }^{275}$

To be sure, nothing in these Amendments or anywhere else in the Constitution explicitly forbids having more jurors, requires secretive interpersonal deliberation of jurors, or bars any of our other proposed reforms. ${ }^{276}$ Even some of the most longstanding practices, like peremptory challenges, find no basis in the Constitution. ${ }^{277}$ As commentators have recently acknowledged, a question like "whether jury trials must be in person [versus online] ostensibly falls in what originalists [call] the 'construction zone'-where legal practitioners are afforded greater (albeit not unlimited) latitude in adjusting constitutional rights." 278 Perhaps some technological changes were unforeseeable, but if the Framers wanted to prevent a jury of 300 citizens from convening, or if they wanted to explicitly require secretive deliberations, they could have said so. To be sure, mere silence on a tech-

272. U.S. Const. amend. VII.

273. See generally Charles W. Wolfram, The Constitutional History of the Seventh Amendment, 57 MinN. L. REv. 639, 640 n.2 (1972) ("In the great majority of state jurisdictions that have a state constitutional right to jury trial in state court proceedings, the test is similar to that employed by the federal courts in interpreting the [S]eventh [A]mendment ....").

274. Justin Sarno \& Jayme Long, Social Distancing and Right to Jury Trial Must Be Reconciled, LAw360 (Apr. 12, 2020, 8:02 PM), https://www.law360.com/articles/ 1261476/social-distancing-and-right-to-jury-trial-must-be-reconciled [https://perma.cc/ U9ZW-P7DJ] (emphasis added and citation omitted).

275. U.S. Const. amend. VI.

276. The Supreme Court has held that as little as six jurors can constitute a jury in civil cases. See Colgrove v. Battin, 413 U.S. 149, 159-60 (1973) (noting that the Court "express[ed] no view as to whether any number less than six would ... satisf[y] the Seventh Amendment's guarantee of trial by jury in civil cases"); $c f$. Ballew v. Georgia, 435 U.S. 223 (1978) (holding that defendant's "trial on criminal charges before a fivemember jury deprived him of the right to trial by jury guaranteed by the Sixth and Fourteenth Amendments"). It has not suggested a maximum limit. $C f$. FED. R. CIV. P. 48 ("A jury must begin with at least [six] and no more than [twelve] members ....").

277. Georgia v. McCollum, 505 U.S. 42, 57 (1992) ("This Court repeatedly has stated that the right to a peremptory challenge may be withheld altogether without impairing the constitutional guarantee of an impartial jury and a fair trial."). See generally Morris B. Hoffman, Peremptory Challenges Should Be Abolished: A Trial Judge's Perspective, 64 U. CHI. L. REv. 809, 810 (1997) ("[T]he benefits of the peremptory challenge system are outweighed by the damage which that system causes to the most basic principles of an impartial jury.").

278. Justin D. Rattey, Gap Filling: Assessing the Constitutionality of Virtual Criminal Trials in Light of Ramos v. Louisiana, 125 Penn ST. L. Rev. Penn Statim 1, 3 (2020). 
nological or procedural innovation should not be read as a proscription against it. ${ }^{279}$

The Supreme Court has written that "[w]hile 'the intent of the Framers' is often an elusive quarry, the relevant constitutional history casts considerable doubt on the easy assumption ... that if a given feature existed in a jury at common law in 1789, then it was necessarily preserved in the Constitution." 280 Indeed, the Founders themselves criticized traditionalists like Edmund Burke for preferring past practice to pragmatic reform. ${ }^{281}$ In this vein, Cass Sunstein highlights Madison's preference for "reflection and choice" over "accident and force." 282 As Jefferson wrote, because of time's passing, "current generations have more experience than past generations." 283

It is, therefore, useful to utilize a functional and purposive analysis that determines what goals the Founders sought to achieve with the jury as an institution and, consequently, which reforms could help further these goals. ${ }^{284}$ As we wrote in the Introduction, those objectives include democratic engagement and the accurate sorting of truth from falsity. The foregoing sections demonstrate how those purposes can be better achieved using contemporary science and technology.

Describing the function of the jury, the Supreme Court wrote that its "purpose is [in large part] attained by the participation of the community in determinations of guilt and by the application of the common sense of laymen who, as jurors, consider the case." $285 \mathrm{We}$ also note the goals of the first Federal Rule of Civil Procedure-to promote the "just, speedy, and efficient" resolution of trials ${ }^{286}$ - and the second Federal Rule of Criminal Procedure- "to provide for the just determination of every criminal proceeding, to secure simplicity in procedure and fairness in administration, and to eliminate unjustifi-

279. $C f$. United States v. Nixon, 418 U.S. 683, 706 n.16 (1974) ("The Special Prosecutor argues that there is no provision in the Constitution for a Presidential privilege as to the President's communications corresponding to the privilege of Members of Congress under the Speech or Debate Clause. But the silence of the Constitution on this score is not dispositive." (emphasis added)).

280. Williams v. Florida, 399 U.S. 78, 92 (1970) (emphasis added).

281. Cass R. Sunstein, Burkean Minimalism, 105 Мich. L. Rev. 353, 398-99 (2006).

282. Id. at 398.

283. Id.

284. See Richard H. Fallon, Jr., A Constructivist Coherence Theory of Constitutional Interpretation, 100 HARV. L. REV 1189, 1200 (1987) (describing an approach to constitutional interpretation analyzing the relevant "values, purposes, or political theory in light of which the Constitution or certain elements of its language and structure are most intelligible").

285. Ballew v. Georgia, 435 U.S. 223, 229 (1978) (citing Williams v. Florida, 399 U.S. 78, 100 (1970)).

286. Fed. R. Civ. P. 1 ("These rules govern the procedure in all civil actions and proceedings in the United States district courts . . . [and] should be construed, administered, and employed by the court and the parties to secure the just, speedy, and inexpensive determination of every action and proceeding." (emphasis added)). 
able expense and delay." 287 Ultimately, "[d]ue process, as [the Supreme] Court often has said, is a flexible concept that varies with the particular situation." 288

Lacking direct Supreme Court holdings on the questions we raise, we consider how the Supreme Court has adapted to technological change in relation to other constitutional rights such as those guaranteed by the Fourth Amendment. In 2001, Justice Scalia, writing for the Court in Kyllo v. United States, concluded that the police's use of thermal-imaging technology to peek through a home's walls was a "search" under the Fourth Amendment even though the police using the technology did not physically enter a home. ${ }^{289}$ The Court reiterated that "[ $\mathrm{t}]$ he Fourth Amendment is to be construed in the light of what was deemed an unreasonable search and seizure when it was adopted, and in a manner which will conserve public interests as well as the interests and rights of individual citizens." ${ }^{290}$ But the ultimate intuition was more functionalist considering what and where the technology allowed the government to see (inside homes). Thus, like a governmental intrusion into a home, the majority found that using such technology was a search and presumptively unreasonable absent a warrant. ${ }^{291}$ We suggest a similar functionalist approach for applying technologies to juries.

In other contexts, courts apply balancing tests. For example, in pretrial discovery, courts weigh whether "good cause" exists for video depositions. ${ }^{292}$ Some scholars, in the first weeks of the pandemic, guessed that a similar approach would apply for online jury trials. ${ }^{293}$ Their predictions proved accurate. ${ }^{294}$ Moving our analysis beyond the pandemic context requires a more nuanced analysis, but the functionalist caselaw provides some guidance.

287. FED. R. CRIM. P. 2.

288. Zinermon v. Burch, 494 U.S. 113, 127 (1990).

289. Kyllo v. United States, 533 U.S. 27, 39-40 (2001).

290. Id. at 40 (quoting Carroll v. United States, 267 U.S. 132, 149 (1925)) (emphasis added).

291. Id. at 40. See also Carpenter v. United States, 138 S. Ct. 2206, 2223 (2018) (police use of a new technology enabling mass acquisition of cell-site records constituted a "search"); id. at 2261 (2018) (Gorsuch, J., dissenting) (grants you the right to invoke its guarantees whenever one of your protected things (your person, your house, your papers, or your effects) is unreasonably searched or seized."); see also Bernard Chao, Catherine Durso, Ian Farrell \& Christopher Robertson, Why Courts Fail to Protect Privacy: Race, Age, Bias, and Technology, 106 Calif. L. Rev. 263, 263 (2018) (discussing how "the police now exploit the 'third party' doctrine to access data held by email and cell phone providers, without securing a warrant, on the Supreme Court's intuition that the public has no expectation of privacy in that information").

292. See Jay E. Grenig \& William C. Gleisner, III, eDiscovery and Digital EVIDENCE § 18:13 (2020).

293. Michael Pressman \& Michael Shammas, Memorandum: The Permissibility \& Constitutionality of Jury Trial by Videoconference, Civ. Jury Project (May 4, 2020), https://civiljuryproject.law.nyu.edu/memorandum-the-permissibility-constitutionalityof-jury-trial-by-videoconference/ [https://perma.cc/38WE-T7TF].

294. See Boutros et al., supra note 47, at 53. 
Beyond a general functionalism about the goals of accuracy and democratic representation, the Constitution provides a few additional lodestars. In what follows, we consider the effect of our reforms on the ideal of public trials and then consider the constitutionality of our reforms under the Constitution's requirements involving impartiality, confrontation, and vicinage, respectively.

\section{B. Public Justice}

American justice is public justice. ${ }^{295}$ As the Supreme Court has written, public criminal trials are "essential" because "the presence of interested spectators ... keep [a defendant's] triers keenly alive to a sense of their responsibility and to the importance of their functions." ${ }^{296}$ Courts have since clarified that civil trials should generally be just as public as criminal ones. The California Supreme Court's rationale is representative: "[T]he public has an interest, in all civil cases, in observing and assessing the performance of its public judicial system." 297

Public trials are also valuable for a less obvious reason. Like an Athenian agora, jury service provides an opportunity to cooperatively evaluate crucial societal issues and to do so in a manner that is increasingly less common in our age where so much debate occurs on either partisan media or in social-media bubbles. John Stuart Mill mirrored this point in Considerations on Representative Government, where he praised the petit jury's institutional ability to prepare citizens to live and participate within democracies by teaching them to evaluate and therefore respect norms. ${ }^{298}$

On this front, little conflict exists between online justice and public justice; increasing use of the former may serve the latter. Indeed, an online pandemic-era trial attracted about 2,000 viewers, many more than could fit into a live courtroom. ${ }^{299}$ Oddly, while permitting audio broadcasts, some courts-especially before the coronavirus-resisted video broadcasts of trials and hearings, as if that were too public. ${ }^{300}$

In addition to streaming public hearings online, during the COVID-19 pandemic several states decided to make hearings available for citizens who lack internet access by setting up viewing rooms in

295. See Judith Resnik, Bring Back Bentham: "Open Courts," "Terror Trials," and Public Sphere(s), 5 L. \& Eтhics Hum. RTs. 1, 2 (2011).

296. Waller v. Georgia, 467 U.S. 39, 46 (1984) (quoting In re Oliver, 333 U.S. 257, 270 n.25 (1948)).

297. NBC Subsidiary (KNBC-TV), Inc. v. Superior Ct. of L.A. Cnty., 980 P.2d 337, 360 (1999) (emphasis in original).

298. John Stuart Mill, Considerations on Representative Government 78-79 (1862).

299. Siegal, supra note 67.

300. See Mary Flood, Windows Opening and Doors Closing-How the Internet Is Changing Courtrooms and Media Coverage of Criminal Trials, 59 Syracuse L. REv. 429, 431 (2009). 
courthouses with spaced seating. ${ }^{301}$ After the coronavirus pandemic ends, public libraries, local and state legislatures, and other communal buildings could continue coordinating with courts to ensure that every citizen, jurors and interested spectators alike, can watch online trials.

Synchronicity is presently a real limitation to the publicity of trials-people can only be in one place at a time. Especially if courts post asynchronous trial videos online, the internet will vastly increase the number of people able to watch trials at their own convenience.

The well-documented decline in the percentage of trials may render the right to a public trial even more important today than it was in Mill's time. ${ }^{302}$ Several of our reforms (such as condensing trial presentations) are designed to make trials less expensive and cumbersome, and others (like larger juries) are designed to make them less risky and unreliable. These advantages may well serve the goals of public justice by facilitating more trials.

\section{The Confrontation Clause}

The Confrontation Clause provides that "in all criminal prosecutions, the accused shall enjoy the right ... to be confronted with the witnesses against him." " 303 Some scholars believe that the Confrontation Clause prevents criminal trials, bench or jury, from being held entirely online unless a defendant consents. ${ }^{304}$ But the exact meaning of "confrontation" remains an open question. In addition, even if "confrontation" does require defendants to be in the same room as their accusers, it is difficult to see why it would also require that jurors be physically present.

We have yet to receive a firm answer from the Supreme Court on whether online trials violate the Sixth Amendment's Confrontation Clause. ${ }^{305}$ Given the rate of technological advancement, it seems likely the Court will eventually uphold the practice-at least in live trials conducted with secure videoconferencing software. ${ }^{306}$ Several

301. See, e.g., Jamiles Lartey, The Judge Will See You on Zoom, but the Public is Mostly Left Out, Marshall Project (Apr. 13, 2020, 6:00 AM), https:// www.themarshallproject.org/2020/04/13/the-judge-will-see-you-on-zoom-but-the-public-is-mostly-left-out [https://perma.cc/RE47-VXJ8].

302. See, e.g., Jocelyn Simonson, The Criminal Court Audience in a Post-Trial World, 127 Harv. L. Rev. 2173, 2177 (2014).

303. U.S. Const. amend. VI.

304. Draper, supra note 86, at I.-3.

305. See id. at I.-7.

306. See, e.g., Dixon, supra note 48, at 37 ("In 2013, I predicted that judges and lawyers would initially resist the idea of remote video hearings but would nevertheless relent because of the impressive nature of high-definition video displays. I also predicted that the Supreme Court would find the Constitution's Sixth Amendment Confrontation Clause satisfied by remote witness appearances, but maybe not within my lifetime." (emphasis added) (internal citation omitted)). 
cases address rights provided by the Confrontation Clause. ${ }^{307} \mathrm{~A}$ subcategory of such cases-involving witness testimony against the accused via closed-circuit television-are useful in discerning how courts would treat confrontation issues in online criminal jury trials. ${ }^{308}$

In Maryland v. Craig, the Court held that the Confrontation Clause does not categorically forbid child abuse victims from testifying against defendants via one-way closed-circuit television. ${ }^{309}$ In deciding the key issue-whether the physical presence of the defendant before his accuser was necessary-Justice O'Connor wrote that "the Confrontation Clause does not prohibit [the] use of a procedure that, despite the absence of face-to-face confrontation, ensures the reliability of the evidence by subjecting it to rigorous adversarial testing and thereby preserves the essence of effective confrontation." ${ }^{310}$ When a sufficient state interest justifies virtual instead of physical confrontation, the Court implied that three conditions must exist to make oneway testimony constitutionally permissible: First, witnesses must testify under oath; second, they must be subject to "full cross-examination"; and third, they must be visible to "the judge, jury, and defendant" when testifying. ${ }^{311}$ If one-way video using pre-1990s technology is constitutional given a sufficient state interest, then two-way video using today's technology may very well meet constitutional muster. ${ }^{312}$ For this reason, several scholars have recently rallied around the idea of using two-way video to satisfy the Confrontation Clause. ${ }^{313}$

307. See, e.g., Kentucky v. Stincer, 482 U.S. 730, 745 (1987) ("[A] defendant is guaranteed the right to be present at any stage of the criminal proceeding that is critical to its outcome if his presence would contribute to the fairness of the procedure."); Illinois v. Allen, 397 U.S. 337, 338 (1970) ("One of the most basic of the rights guaranteed by the Confrontation Clause is the accused's right to be present in the courtroom at every stage of his trial.").

308. E.g., Maryland v. Craig, 497 U.S. 836, 857 (1990).

309. Id.

310. $I d$.

311. Id. ("Because there is no dispute that the child witnesses in this case testified under oath, were subject to full cross-examination, and were able to be observed by the judge, jury, and defendant as they testified, we conclude that, to the extent that a proper finding of necessity has been made, the admission of such testimony would be consonant with the Confrontation Clause." (emphasis added)).

312. See United States v. Gigante, 166 F.3d 75, 81 (2d Cir. 1999) (deciding not to apply the Craig standard because the trial court's use of two-way video "preserved the face-to-face confrontation").

313. E.g., J. Benjamin Aguiñaga, Comment, Confronting Confrontation in a FaceTime Generation: A Substantial Public Policy Standard to Determine the Constitutionality of Two-Way Live Video Testimony in Criminal Trials, 75 LA. L. REv. 175, 177 (2014); see also Will Resnik, Comment, Get with the Times: Why the Use of Live TwoWay Video Testimony Does Not Violate the Confrontation Clause, 45 Am. J. CRIM. L. 461, 464, 480 (2019) ("[T]he use of two-way video testimony does not violate the Confrontation Clause."); Hadley Perry, Comment, Virtually Face-to-Face: The Confrontation Clause and the Use of Two-Way Video Testimony, 13 Roger Williams U. L. REv. 565, 567-68 (2008) ("[L]ive two-way video testimony is constitutional” because "its use is consistent with the . . common law right of confrontation," its use is 
State analogues to the federal Confrontation Clause vary. Some state constitutions have been interpreted to categorically bar testimony via videoconferencing in criminal jury trials. ${ }^{314}$ Massachusetts, for example, requires "face-to-face" confrontation. ${ }^{315}$ But others allow digital testimony. ${ }^{316}$ For example, in People $v$. Wrotten, the New York Court of Appeals ruled in 2009 that-absent a statutory proscription-trial courts are free to order two-way video testimony when circumstances (there, an ill witness) require it. ${ }^{317}$ More importantly, the court used logic that could apply even absent exigent circumstances, writing that, "live two-way video may preserve the essential safeguards of testimonial reliability, and so satisfy the Confrontation Clause's primary concern with ensuring the reliability of the evidence against a criminal defendant by subjecting it to rigorous testing in the context of an adversary proceeding before the trier of fact." 318

Of course, if given the choice between a traditional trial versus one fully embracing our six reforms, innocent risk-averse defendants may well prefer the latter. Nonetheless, the logic in cases like Wrotten should expand to allow for video-based confrontation even absent exigent circumstances and even without the consent of defendants. Eventually, the state's own interests in accurate outcomes, democratic representation on juries, and efficiency of trial processes may override contrary objections.

\section{The Implications for Procedural Rules}

If our reforms in Part II are adopted, key goals of both criminal and civil juries might be strengthened. These are articulated in the first Federal Rule of Civil Procedure - to promote the "just, speedy, and efficient" resolution of trials ${ }^{319}$ - and the second Federal Rule of Criminal Procedure- "to provide for the just determination of every criminal proceeding, to secure simplicity in procedure and fairness in administration, and to eliminate unjustifiable expense and delay." ${ }^{320}$ Here, we briefly analyze how, if large-scale online jury trials become a

"more protective of defendants' interests," and its use is "cost-efficient and convenient.").

314. Commonwealth v. Bergstrom, 524 N.E.2d 366, 371 (Mass. 1988); see also People v. Fitzpatrick, 633 N.E.2d 685, 687 (Ill. 1994) (interpreting the Illinois Constitution's confrontation clause).

315. Bergstrom, 524 N.E.2d at 371; accord Fitzpatrick, 633 N.E.2d at 687 ("[A] defendant is entitled to a face-to-face confrontation with a witness.").

316. See, e.g., People v. Phillips, 315 P.3d 136, 152 (Colo. App. 2012) (citing Maryland v. Craig, 497 U.S. 836, 855-57 (1990), and holding that neither the Colorado nor federal Constitution render CCTV testimony unconstitutional).

317. People v. Wrotten, 923 N.E.2d 1099, 1103 (N.Y. 2009).

318. Id. at 1102 (alterations incorporated) (citation and quotation marks omitted).

319. Fed. R. Civ. P. 1.

320. Fed. R. CRIM. P. 2. 
reality, state and federal procedures must change. We use the two sets of federal rules as jumping-off points.

Several changes to the Federal Rules of Criminal Procedure could make clear that online proceedings are permissible. For instance, Federal Rule of Criminal Procedure 1-detailing definitions and scopedefines "telephone" as "any technology for transmitting live electronic voice communication" but has no provisions for simultaneous video for situations when more than audio is required. ${ }^{321}$ Other terms like "place of prosecution and trial" could be revised, ${ }^{322}$ and the Rules ubiquitously refer to proceedings "before" judicial officers and could clarify if "before" implies a physical presence. ${ }^{323}$

A second useful change involves adapting existing provisions for video evidence to jury trials. For example, Federal Rule of Criminal Procedure 5(f), concerning initial appearances, stipulates that "video teleconferencing may be used to conduct an appearance . . . if the defendant consents." ${ }^{324}$ Federal Rule of Criminal Procedure 10 likewise allows for videoconferencing during arraignments if consent is given. ${ }^{325}$ Interestingly, the 2002 Committee Notes permitting videoconferencing noted as follows:

The Committee was satisfied that the technology has progressed to the point that video teleconferencing can address the concerns raised in the past about the ability of the court and the defendant to see each other and for the defendant and counsel to be in contact with each other, either at the same location or by a secure remote connection. ${ }^{326}$

This recognition, in turn, supports the notion that online trials can satisfy not only the Confrontation Clause but also the right to effective counsel so long as reliability concerns articulated in cases like Craig are addressed. Twenty years later, the Committee Notes could again be updated to reflect improvements made possible since then.

Another change might involve creating an entirely new rule detailing how online jury trials should be conducted, not unlike the Federal Rules of Civil Procedure's stipulations regarding best-practices for out-of-court witness testimony discussed below. ${ }^{327}$ The rule drafters might benefit from examining several of the coronavirus-era protocols mentioned earlier. ${ }^{328}$

Beyond the procedural rules, Congress could revisit the Sixth Amendment's Vicinage Clause, which requires that a trial be in the

321. See id. at 1.

322. Id. at 18 .

323. E.g., id. at 1.

324. Id. at $5(\mathrm{~g})$.

325. Id. at $10(\mathrm{c})$.

326. Id.

327. See Fed. R. Civ. P. 43(a).

328. See generally supra Part I. 
"State and district wherein the crime [was] committed." 329 Congress could provide for statewide districts, which would thereby increase the geographic scope and diversity of juries, reducing biases of localism. ${ }^{330}$ Importantly, at least three federal circuits have held that the Clause does not apply to the states, clearing the way for statewide juries in state cases as well. ${ }^{331}$

The Federal Rules of Civil Procedure and state analogues would not require changes as far-reaching as those required for criminal procedure rules. Most would merely modify definitions. Currently, Federal Rule of Civil Procedure 43(a) provides that "[f]or good cause in compelling circumstances and with appropriate safeguards, the court may permit testimony in open court by contemporaneous transmission from a different location," and the 1996 Advisory Committee noted that video is generally the preferrable means of transmission. ${ }^{332}$ An advisory committee could now go further to explicate the "appropriate safeguards" for video testimony for not only witnesses but also attorneys and jurors. The same issues-involving concerns like economic and temporal efficiency, pragmatism, and the ease of credibility determinations-arise. For example, "the relative cost of transporting" witnesses to court, as well as the ability of the court to subpoena witnesses-both factors in Rule 43(a) — could analogously be used to suggest best practices for online juries, especially in evaluating courts' abilities to empanel a representative jury. ${ }^{333}$

Rule 43(a) exemplifies the experience judges already have with videoconferencing in civil matters. Some state rules already mirror 43(a): Maine requires that testimony typically be in "open court" while allowing "contemporaneous transmission from a different location" upon a demonstration of "good cause." 334 Accordingly, state policymakers could also use Rule $43(\mathrm{a})$ as a guide. ${ }^{335}$

329. U.S. Const. amend. VI.

330. Williams v. Florida, 399 U.S. 78, 96 (1970) ("Congress [has] the power to determine the actual size of the "vicinage' by its creation of judicial districts.").

331. Caudill v. Scott, 857 F.2d 344, 345 (6th Cir. 1988); Cook v. Morrill, 783 F.2d 593, 595 (5th Cir. 1986); Zicarelli v. Dietz, 633 F.2d 312, 318 (3d Cir. 1980).

332. FED. R. Civ. P. 43(a) (describing when testimony need not be taken in "open court" and can instead be taken by video); see also United States v. Guild, No. 1:07cr404, 2008 WL 191184, at*2 (E.D. Va. Jan. 17, 2008) (applying the rule to a criminal case where confrontation was not an issue).

333. See Daniel Devoe \& Sarita Frattaroli, Videoconferencing in the Courtroom: Benefits, Concerns, and How to Move Forward, Mass. Soc. L. LiBr. 8-9, http:// socialaw.com/docs/default-source/judge-william-g.-young/judging-in-the-american-legal-system/04devoe-sarita-paper.pdf [https://perma.cc/HQ79-XHAU]. Though it focuses on courts ability to use their subpoena power over proposed witnesses, in the context of an online jury trial, a similar test-the ability of the court to bring jurors to court-seems pertinent. Id.

334. ME. R. Civ. P. 43(a) (emphasis added).

335. Cf. Guild, 2008 WL 191184, at*3 ("Recognizing both the importance of live testimony in a criminal trial and the fact that the Confrontation Clause is not impli- 
Ultimately, notwithstanding the need to reconsider procedural rules, adopting our reforms should generally lessen complexity. For example, several of the most debated procedural rules that our proposals implicate_-venue rules, for instance ${ }^{336}$ - may become less convoluted because our national jury-pool reform reduces forumshopping incentives.

\section{CONClusion}

The Founders would not recognize how we build bridges, treat cancer, or transport ourselves. Yet the modern jury trial would be oddly familiar. Such stagnation would disappoint them. As James Madison remarked, "Is it not the glory of the people of America, that whilst [Americans] have paid a decent regard to the opinions of former times and other nations, they have not suffered a blind veneration for antiquity, for custom, or for names, to over-rule . . . experience?"337

We have suggested that, if invented today-after the peculiar experience of COVID-19 and with 232 years of scientific, political, and social experience-the jury trial would look quite different. Since the institution is supposed to accomplish its essential functions of facilitating democratic deliberation and accurately resolving issues of public importance, it should look quite different. ${ }^{338}$ Under a new model, we might convene fifty or more jurors; utilize condensed videos to integrate evidence, arguments, and jury instructions; and even allow jurors to render individual, mathematically aggregated decisions privately in a time and place of their choosing.

Although some of the reforms seem radical, this is only because of how radically static the jury as an institution has remained despite post-1789 scientific and social developments. Our reforms are no more radical than overused alternatives to physical jury trials like mandatory arbitration, and are likely both more constitutional and more faithful to the jury's animating values. Online jury trials are surely less offensive to the Seventh Amendment than the increasing use of contracts of adhesion that incorporate a combination of classaction waivers and arbitration agreements to effectively nullify the Seventh Amendment right to a civil jury trial. ${ }^{339}$

cated by this testimony, the Court will use Federal Rule of Civil Procedure 43(a) as the threshold showing for the use of video testimony . ...").

336. 28 U.S.C. $§ 1391(b)$ (2011).

337. The Federalist No. 14, at 72 (James Madison) (George W. Carey \& James McClellan eds., 2001).

338. See supra Part I.

339. Courts have, in especially egregious cases, struck down arbitration clauses. See, e.g., Sevier Cnty. Schs. Fed. Credit Union v. Branch Banking \& Tr. Co., 990 F.3d 470, 476-79 (6th Cir. 2021) (listing cases striking down arbitration clauses in egregious situations). Nonetheless, unless bad faith exists or a change-of-terms provision's scope is unreasonably exceeded, courts rarely find mandatory arbitration agreements to be 
And of course, these reforms need not be implemented all at once. In the shorter term, we might opt for less extreme reforms-conducting more online jury trials to enable larger jury pools or aggregating the decisions of several parallel juries instead of several individual jurors, thereby preserving deliberation while retaining the benefits of scale.

Ultimately, our reforms enhance the jury trial's ability to achieve its essential goals: giving the people-not elites-the power to accurately decide cases and determine societal norms. ${ }^{340}$

unconscionable, especially since the Supreme Court's decision in AT\&T Mobility LLC v. Concepcion, 563 U.S. 333, 351-52 (2011).

340. See Blackstone, supra note 11 , at $* 378$. 